\title{
From a PGeP Pincer-Type Germylene to Metal Complexes Featuring Chelating (Ir) and Tripodal (Ir) PGeP Germyl and Bridging ( $\left.\mathrm{Mn}_{2}\right)$ and Chelating (Ru) PGeP Germylene Ligands
}

Javier Brugos, ${ }^{a}$ Javier A. Cabeza, ${ }^{* a}$ Pablo García-Álvarez, ${ }^{a}$ and Enrique Pérez-Carreño ${ }^{b}$

${ }^{a}$ Centro de Innovación en Química Avanzada (ORFEO-CINQA), Departamento de Química Orgánica e Inorgánica, Universidad de Oviedo, 33071 Oviedo, Spain

bepartamento de Química Física y Analítica, Universidad de Oviedo, 33071 Oviedo, Spain

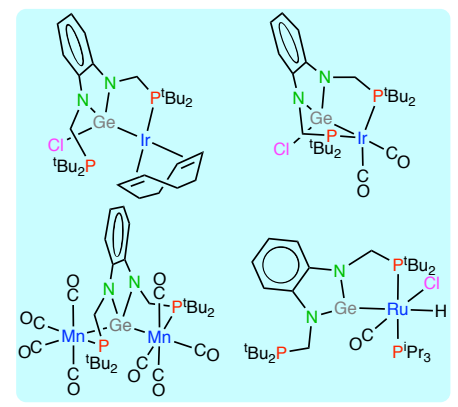

TOC graphic 
ABSTRACT: Different coordination modes of a PGeP chloridogermyl ligand $(G e, P$-chelating and $P, G e, P$-tripodal) and a PGeP germylene ligand $(P, G e, P$-bridging and $G e, P$-chelating) have been identified in coordination compounds resulting from reactions of the PGeP pincer-type diphosphane-germylene $\mathrm{Ge}\left(\mathrm{NCH}_{2} \mathrm{P}^{t} \mathrm{Bu}_{2}\right)_{2} \mathrm{C}_{6} \mathrm{H}_{4}$ (1) with iridium(I), manganese(0), and ruthenium(II) complex reagents. Germylene 1 reacted with $\left[\operatorname{Ir}_{2}(\mu-C l)_{2}\left(\eta^{4}-\operatorname{cod}\right)_{2}\right](\operatorname{cod}=1,5-$ cyclooctadiene) to give $\left[\operatorname{Ir}\left\{\kappa^{2} G e, P-\mathrm{GeCl}\left(\mathrm{NCH}_{2} \mathrm{P}^{t} \mathrm{Bu}_{2}\right)_{2} \mathrm{C}_{6} \mathrm{H}_{4}\right\}\left(\eta^{4}\right.\right.$-cod) $)(2)$, which contains a $G e, P$ chelating PGeP chloridogermyl ligand and an uncoordinated phosphane group that weakly interacts with the Ge atom. Carbon monoxide readily displaced the cod ligand of $\mathbf{2}$ to give the dicarbonyl derivative $\left[\operatorname{Ir}\left\{\kappa^{3} P, G e, P-\mathrm{GeCl}\left(\mathrm{NCH}_{2} \mathrm{P}^{t} \mathrm{Bu}_{2}\right)_{2} \mathrm{C}_{6} \mathrm{H}_{4}\right\}(\mathrm{CO})_{2}\right]$ (3), in which the PGeP chloridogermyl ligand displays a $P, G e, P$-tripodal coordination mode. A bridging germylene moiety has been identified in the binuclear derivative $\left[\mathrm{Mn}_{2}\left\{\mu-\kappa^{3} P, G e, P-\right.\right.$ $\left.\left.\mathrm{Ge}\left(\mathrm{NCH}_{2} \mathrm{P}^{t} \mathrm{Bu}_{2}\right)_{2} \mathrm{C}_{6} \mathrm{H}_{4}\right\}(\mathrm{CO})_{8}\right]$ (4), which resulted from the treatment of $\left[\mathrm{Mn}_{2}(\mathrm{CO})_{10}\right]$ with germylene 1. The ruthenium complex $\left[\mathrm{RuHCl}(\mathrm{CO})\left\{\kappa^{2} G e, P-\mathrm{Ge}\left(\mathrm{NCH}_{2} \mathrm{P}^{t} \mathrm{Bu}_{2}\right)_{2} \mathrm{C}_{6} \mathrm{H}_{4}\right\}\left(\mathrm{P}^{i} \mathrm{Pr}_{3}\right)\right]$ (5), which was isolated from the reaction of 1 with $\left[\mathrm{RuHCl}(\mathrm{CO})\left(\mathrm{P}^{i} \operatorname{Pr}_{3}\right)_{2}\right]$, is the first transition metal derivative of $\mathbf{1}$ in which the germylene moiety has not inserted into an $\mathrm{M}-\mathrm{M}$ or $\mathrm{M}-\mathrm{Cl}$ bond $(\mathrm{M}=$ transition metal), as it contains germylene 1 coordinated in a $G e, P$-chelating mode, the resulting GeNCPRu ring being severely strained due to the short length of the coordinated $\mathrm{CH}_{2} \mathrm{P}^{t} \mathrm{Bu}_{2}$ arm, which also forces the germanium atom to be in an uncommon T-shaped environment. DFT calculations have been used to shed light on bonding features of complexes $\mathbf{2}$ and $\mathbf{5}$. The X-ray structures of 1-5 are also reported. 


\section{INTRODUCTION}

The use of heavier carbene analogues, also called heavier tetrylenes, as ligands in transition metal chemistry has increased a lot in the last few years. ${ }^{1}$ This intense research activity has been stimulated by their ambiphilic character (they can behave as Lewis bases and acids), their strong electron-donating capacity (those that are donor-stabilized are even stronger electron-donors than most phosphanes and $\mathrm{N}$-heterocyclic carbenes $^{2}$ ), and by the discovery that some of their complexes are efficient catalyst precursors for homogeneous catalytic transformations. ${ }^{3,4}$

On the other hand, many efforts have also been devoted in the last two decades to the design and synthesis of pincer ligands comprising strong electron-donating groups because transition metal complexes containing such ligands have been successfully used in many stoichiometric $^{5}$ and catalytic reactions ${ }^{5,6}$ involving bond activation processes (strong electrondonating ligands facilitate the participation of their complexes in oxidative addition reactions ${ }^{7}$ ).

Despite the increasing interest in heavier tetrylenes and pincer ligands, very few pincertype ligands (free or forming part of transition metal complexes) have been reported to be equipped with at least one heavier tetrylene as donor group: Hahn and coworkers have described GeNGe and GeCGe pincers in which a pyridine-2,6-diyl or a benzene-1,3-diyl group, respectively, are linked to two 2-germabenzimidazol-2-ylidene fragments, ${ }^{8}$ and also the $\mathrm{NSnN}$ pincers $\mathrm{Sn}\left\{\mathrm{N}\left(\mathrm{CH}_{2}\right)_{\mathrm{n}} \mathrm{NMe}_{2}\right\}_{2} \mathrm{C}_{6} \mathrm{H}_{4}(\mathrm{n}=1,2),{ }^{9}$ but their behavior as ligands has not been investigated; the Driess group has described the synthesis, some coordination chemistry, and catalytic applications of $\mathrm{ECE}^{10}$ and $\mathrm{ENE}^{11}$ pincers having benzamidinato-silylenes or -germylenes as E-donor groups; the groups of Whited, ${ }^{12}$ Ozerov ${ }^{13}$ and Zybill ${ }^{14}$ have reported some transition metal complexes containing the PSiP pincers $\mathrm{Si}\left(\mathrm{C}_{6} \mathrm{H}_{4} \mathrm{PPh}_{2}\right)_{2},{ }^{12} \mathrm{Si}\left(\mathrm{C}_{6} \mathrm{H}_{4} \mathrm{P}^{i} \mathrm{Pr}_{2}\right)_{2}{ }^{13}$ and $\mathrm{Si}\left(\mathrm{C}_{6} \mathrm{H}_{4} \mathrm{CH}_{2} \mathrm{PPh}_{2}\right)_{2},{ }^{14}$ respectively, but their syntheses used silanes instead of free silylenes; and we have recently communicated the synthesis and some transition metal derivative chemistry of the metal-free pincer-type $\mathrm{PGeP}$ germylene $\mathrm{Ge}\left(\mathrm{NCH}_{2} \mathrm{P}^{\prime} \mathrm{Bu}_{2}\right)_{2} \mathrm{C}_{6} \mathrm{H}_{4}{ }^{15,16}$ and $\mathrm{PSnP}$ stannylene $\mathrm{Sn}\left(\mathrm{NCH}_{2} \mathrm{P}^{\prime} \mathrm{Bu}_{2}\right)_{2} \mathrm{C}_{6} \mathrm{H}_{4} \cdot{ }^{17}$

Our above-mentioned studies on the reactivity of germylene $\mathrm{Ge}\left(\mathrm{NCH}_{2} \mathrm{P}^{\prime} \mathrm{Bu}_{2}\right)_{2} \mathrm{C}_{6} \mathrm{H}_{4}(\mathbf{1})$ with transition metal complexes provided reaction products that resulted from the insertion of the $\mathrm{Ge}$ atom of 1 into $\mathrm{Co}-\mathrm{Co}^{15}$ or $\mathrm{M}-\mathrm{Cl}\left(\mathrm{M}=\mathrm{Rh},{ }^{15} \mathrm{Ni},{ }^{16} \mathrm{Pd},{ }^{16} \mathrm{Pt}^{16}\right)$ bonds, but in no instance we obtained 
a product derived from the simple coordination (not insertion) of the germylene fragment to a metal atom. We now report the hitherto unknown X-ray diffraction (XRD) structure of germylene 1 and that the reactions of this PGeP pincer-type germylene with common iridium(I), manganese(0), and ruthenium(II) complexes have afforded transition metal derivatives in which we have characterized chelating and tripodal PGeP germyl (Ir), bridging PGeP germylene $\left(\mathrm{Mn}_{2}\right)$, and unprecedented chelating PGeP germylene ( $\mathrm{Ru}$ ) ligands, the latter also representing the first ruthenium complex to have a non-donor-stabilized N-heterocyclic germylene coordinated as a terminal ligand.

\section{RESULTS AND DISCUSSION}

XRD Structure of Germylene 1. At the time we communicated the synthesis of germylene 1 (Scheme 1), ${ }^{15}$ its molecular structure could not be unambiguously determined. It was inferred from spectroscopic data and from DFT calculations. A subsequent in depth DFT study on PEP tetrylenes of the type $\mathrm{E}\left(\mathrm{NCH}_{2} \mathrm{P}^{\prime} \mathrm{Bu}_{2}\right)_{2} \mathrm{C}_{6} \mathrm{H}_{4}(\mathrm{E}=\mathrm{C}, \mathrm{Si}, \mathrm{Ge}, \mathrm{Sn})$ concluded that the most stable conformation of the molecules with $\mathrm{E}=\mathrm{Ge}$ and $\mathrm{Sn}$ has the lone pairs of both $\mathrm{P}$ atoms weakly interacting with empty orbitals with a large participation of the Ge atom, resulting in unexpectedly short separations between the $\mathrm{E}$ and $\mathrm{P}$ atoms, but this is not the case for the lighter tetrylenes $(\mathrm{E}=$ $\mathrm{C}, \mathrm{Si}) .{ }^{17}$

Scheme 1. Synthesis of Germylene 1

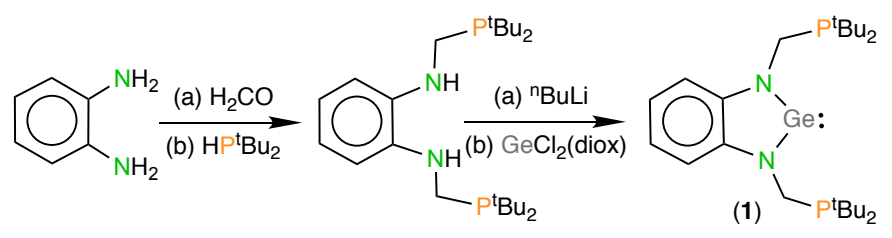

After many attempts, we have now been able to crystallize germylene $\mathbf{1}$ and its molecular structure has finally been determined by XRD. Figure 1 confirms that 1 has $C_{2}$ symmetry and that the $\mathrm{P}$ atoms, which are almost in the plane defined by the atoms of the 2-germabenzimidazol-2ylidene fragment, are only 3.320(2) ̊̊ away from the Ge atom, a distance that is $0.6 \AA$ shorter than the sum of van der Waals radii of these elements. ${ }^{18}$ This structure is similar to that of the tin analogue $\mathrm{Sn}\left(\mathrm{NCH}_{2} \mathrm{P}^{\prime} \mathrm{Bu}_{2}\right)_{2} \mathrm{C}_{6} \mathrm{H}_{4}$, in which the $\mathrm{Sn} \cdots \mathrm{P}$ distances are 3.277(1) and 3.313(1) $\AA$ (in this case, the molecule is not symmetric). ${ }^{17}$ 

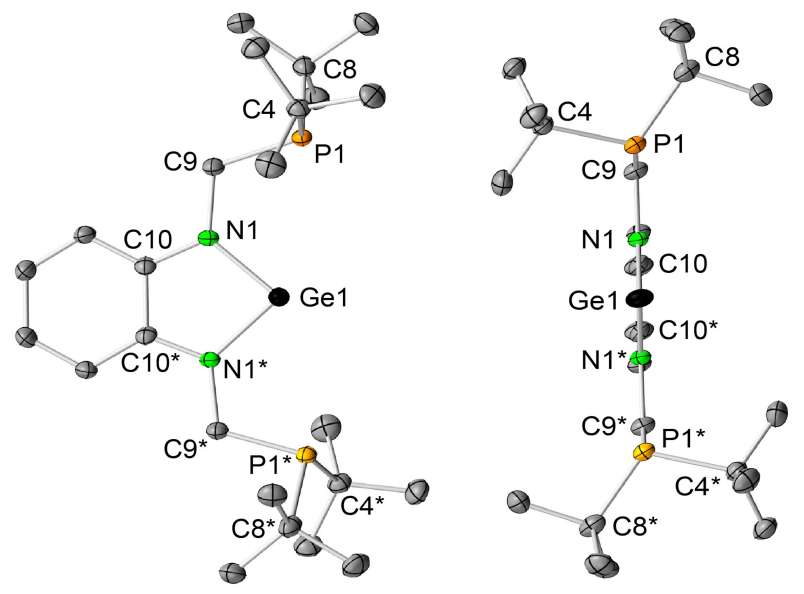

Figure 1. Two views of the XRD molecular structure of germylene 1 (35\% displacement ellipsoids; $\mathrm{H}$ atoms omitted for clarity; starred atoms are related to unstarred ones by a $C_{2}$ symmetry axis). Selected interatomic distances ( $\AA$ ) and angles $\left({ }^{\circ}\right)$ : Ge1․PP1 3.320(2), Ge1-N1 1.879(4), P1-C4 1.890(5), P1-C8 1.880(6), P1-C9 1.861(5), N1-C9 1.473(5), $\mathrm{N} 1-\mathrm{C} 101.379(6), \mathrm{C} 10-\mathrm{C} 10 * 1.436(9) ; \mathrm{N} 1-\mathrm{Ge} 1-\mathrm{N} 1 * 84.0(2)$.

Iridium(I) Derivatives of Germylene 1. The iridium(I) dimer $\left[\mathrm{Ir}_{2}(\mu-\mathrm{Cl})_{2}\left(\eta^{4}-\mathrm{cod}\right)_{2}\right](\operatorname{cod}=$ 1,5-cyclooctadiene) reacted readily with germylene $\mathbf{1}$ (1:2 mole ratio) to give the chloridogermyl complex $\left[\operatorname{Ir}\left\{\kappa^{2} G e, P-\mathrm{GeCl}\left(\mathrm{NCH}_{2} \mathrm{P}^{\prime} \mathrm{Bu}_{2}\right)_{2} \mathrm{C}_{6} \mathrm{H}_{4}\right\}\left(\eta^{4}\right.\right.$-cod) $]$ (2) as the only reaction product (Scheme 2).

\section{Scheme 2. Synthesis of Complexes 2 and 3}
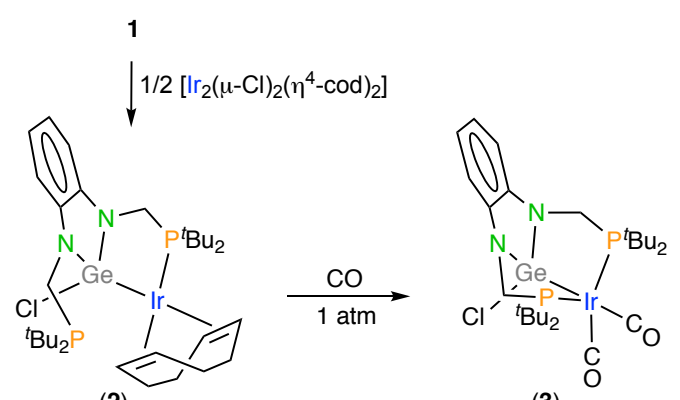

An XRD study (Figure 2) confirmed the insertion of the Ge atom into an $\mathrm{Ir}-\mathrm{Cl}$ bond and that the resulting PGeP chloridogermyl ligand is $G e, P$-chelated to an $\operatorname{Ir}\left(\eta^{4}\right.$-cod $)$ fragment. Therefore, the complex maintains an uncoordinated phosphane fragment. This feature was also suggested by the ${ }^{31} \mathrm{P}\left\{{ }^{1} \mathrm{H}\right\}$ NMR spectrum of 2 , which contains two uncoupled resonances at 75.9 (coordinated P) and 29.7 (free P) ppm. The Ir-Ge bond distance, 2.4275(3) A, is comparable to those measured in other iridium(I) complexes containing germyl ligands. ${ }^{19}$ The insertion of non-donor-stabilized germylenes into $\mathrm{Ir}-\mathrm{Cl}$ bonds has seldom been observed..$^{20}$ For comparison, it should be noted that 
the metal atoms of the related known PSiP silyl rhodium complexes $\left[\mathrm{Rh}\left\{\kappa^{3} P, S i, P\right.\right.$ $\left.\operatorname{SiCl}\left(\mathrm{C}_{6} \mathrm{H}_{4} \mathrm{PPh}_{2}\right)_{2}\right\}\left(\eta^{4}\right.$-cod $\left.)\right] \quad$ and $\quad\left[\mathrm{Rh}\left\{\kappa^{3} P, \operatorname{Si}, P-\operatorname{Si}(\mathrm{OTf})\left(\mathrm{C}_{6} \mathrm{H}_{4} \mathrm{PPh}_{2}\right)_{2}\right\}\left(\eta^{4}-\mathrm{nbd}\right)\right] \quad(\mathrm{nbd} \quad=$ norbornadiene), which were respectively prepared from the silane $\mathrm{H}_{2} \mathrm{Si}\left(\mathrm{C}_{6} \mathrm{H}_{4} \mathrm{PPh}_{2}\right)_{2}$ and $\left[\mathrm{Rh}_{2}(\mu\right.$ $\left.\mathrm{Cl})_{2}\left(\eta^{4}-\mathrm{cod}\right)_{2}\right]$ or $\left[\mathrm{Rh}\left(\eta^{4}-\mathrm{nbd}\right)_{2}\right] \mathrm{OTf}$, are pentacoordinated, ${ }^{21}$ probably because the smaller size of their phosphane groups allows a tridentate coordination of the corresponding PSiP silyl ligand in the presence of the $\eta^{4}$-diene ligand.

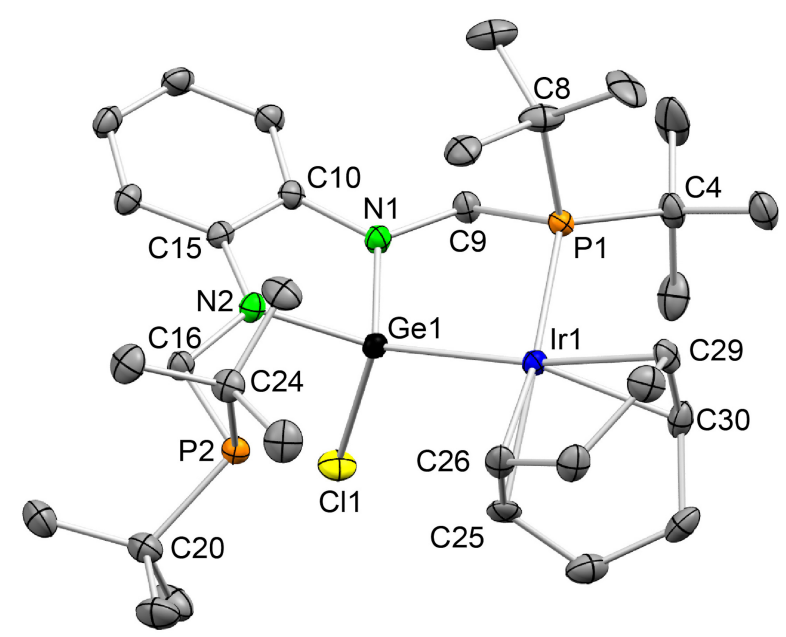

Figure 2. XRD molecular structure of complex 2 (35\% displacement ellipsoids; $H$ atoms omitted for clarity; only one of the two positions in which the methyl groups attached to C8 are disordered is shown). Selected bond distances ( $\mathrm{A})$ and angles $\left(^{\circ}\right)$ : Ir1-C25 2.199(3), Ir1-C26 2.188(2), Ir1-C29 2.193(2), Ir1-C30 2.202(3), Ir1-P1 2.3652(6), Ir1-Ge1

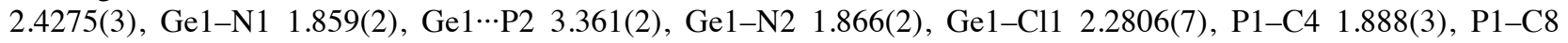
1.903(3), P1-C9 1.865(2), P2-C16 1.854(2), P2-C20 1.890(3), P2-C24 1.890(3), N1-C9 1.430(3), N1-C10 1.374(3), N2-C15 1.399(3), N2-C16 1.451(3), C10-C15 1.421(4), C25-C26 1.395(4), C29-C30 1.402(4); P1-Ir1-Ge1 82.45(2), N1-Ge1-N2 85.78(9), N1-Ge1-Cl1 105.12(7), N2-Ge1-Cl1 99.15(7), N1-Ge1-Ir1 106.00(7), N2-Ge1Ir1 142.04(6), Cl1-Ge1-Ir1 111.68(2).

A remarkable feature of the structure of complex $\mathbf{2}$ is that its uncoordinated $\mathrm{P}$ atom is in the proximity of the Ge atom, at a distance, 3.361(2) $\AA$, that is only $0.041 \AA$ longer than that found in free germylene 1. A similar structural feature has also been observed in the related rhodium complex $\left[\mathrm{Rh}\left\{\kappa^{2} G e, P-\mathrm{GeCl}\left(\mathrm{NCH}_{2} \mathrm{P}^{t} \mathrm{Bu}_{2}\right)_{2} \mathrm{C}_{6} \mathrm{H}_{4}\right\}\left(\eta^{4}\right.\right.$-cod $\left.)\right]$, in which the separation between the uncoordinated $\mathrm{P}$ atom and the Ge atom is 3.364(3). ${ }^{15}$ Aiming at obtaining a rationale that could account for these structural observations, a DFT study on complex $\mathbf{2}$ was performed. An analysis of the NBO second-order perturbation donor-acceptor interactions revealed a non negligible interaction, $12.3 \mathrm{kcal} \mathrm{mol}^{-1}$, between the lone pair of the uncoordinated $\mathrm{P}$ atom and the LUMO of the molecule, which is mainly contributed by the Ge atom and has a slight $\sigma^{*}(\mathrm{Ge}-\mathrm{N})$ character (Figure 3). Analogous theoretical studies have shown that weak P $\cdots E(E=G e$ or $\mathrm{Sn})$ donor- 
acceptor interactions are also responsible for the most stable conformations of germylene $\mathbf{1}$, its tin analogue, and also the ruthenium chloridostannyl complex $\left[\mathrm{RuCl}\left\{\kappa^{2} S n, P\right.\right.$ $\left.\mathrm{SnCl}\left(\mathrm{NCH}_{2} \mathrm{P}^{t} \mathrm{Bu}_{2}\right)_{2} \mathrm{C}_{6} \mathrm{H}_{4}\right\}\left(\eta^{6}\right.$-cym $\left.)\right]($ cym $=p$-cymene $) .{ }^{17}$

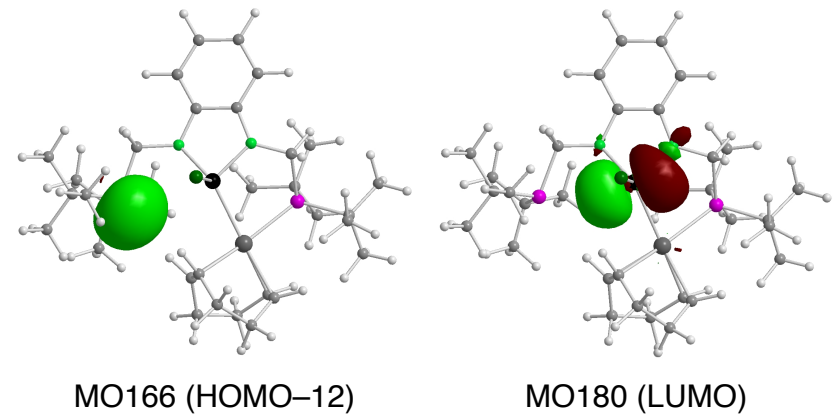

Figure 3. Filled (left) and empty (right) orbitals of complex 2 involved in the weak donor-acceptor interaction that accounts for the close proximity of the uncoordinated phosphane group to the Ge atom (NBO second-order perturbation donor-acceptor interaction analysis).

The dicarbonyl derivative $\left[\operatorname{Ir}\left\{\kappa^{3} P, G e, P-\mathrm{GeCl}\left(\mathrm{NCH}_{2} \mathrm{P}^{t} \mathrm{Bu}_{2}\right)_{2} \mathrm{C}_{6} \mathrm{H}_{4}\right\}(\mathrm{CO})_{2}\right] \quad$ (3) was quantitatively formed when a solution of complex 2 in toluene was exposed to a $\mathrm{CO}$ atmosphere (Scheme 2). Two strong $v_{\mathrm{CO}}$ absorptions, at 2001 and $1956 \mathrm{~cm}^{-1}$, were observed in the IR spectrum of the resulting solution; the low $v_{\mathrm{CO}}$ values indicate that the metal atom is electron rich (the two phosphane fragments and the germyl ligand are strong electron-donors). Its ${ }^{1} \mathrm{H},{ }^{13} \mathrm{C}\left\{{ }^{1} \mathrm{H}\right\}$, and ${ }^{31} \mathrm{P}\left\{{ }^{1} \mathrm{H}\right\}$ NMR spectra indicated mirror molecular symmetry $\left(C_{\mathrm{S}}\right)$, with the ${ }^{31} \mathrm{P}$ resonance appearing at a vey high chemical shift, 116.3 ppm (in $\mathrm{C}_{6} \mathrm{D}_{6}$ ), suggesting a strained coordination of both phosphane fragments (as has been previously observed in the PGeP pincer chloridogermyl squareplanar metal derivatives $\left[\mathrm{Rh}\left\{\kappa^{3} P, G e, P-\mathrm{GeCl}\left(\mathrm{NCH}_{2} \mathrm{P}^{t} \mathrm{Bu}_{2}\right)_{2} \mathrm{C}_{6} \mathrm{H}_{4}\right\}(\mathrm{CO})\right]^{15}$ and $\left[\mathrm{MCl}\left\{\kappa^{3} P, G e, P-\right.\right.$ $\left.\left.\left.\mathrm{GeCl}\left(\mathrm{NCH}_{2} \mathrm{P}^{t} \mathrm{Bu}_{2}\right)_{2} \mathrm{C}_{6} \mathrm{H}_{4}\right\}\right](\mathrm{M}=\mathrm{Ni}, \mathrm{Pd}, \mathrm{Pt})\right){ }^{16}$ The XRD structure of complex 3 (Figure 4) confirmed the tridentate coordination of the PGeP chloridogermyl ligand and the presence of two $\mathrm{CO}$ ligands on the iridium atom, which is in a distorted trigonal bipyramidal ligand environment with the Ge atom and a $\mathrm{CO}$ ligand in the axial positions. The observed distortion is caused by the short length of the $\mathrm{CH}_{2} \mathrm{P}^{t} \mathrm{Bu}_{2}$ side arms, which does not allow the $\mathrm{P}$ atoms to reach the ideal equatorial plane of the bipyramid and forces the $\mathrm{N}$ atoms to be in a pyramidal environment (ideally, $\mathrm{sp}^{2}$-hybridized $\mathrm{N}$ atoms are trigonal planar). In contrast to complex $\mathbf{2}$, in which the larger cod ligand only allows a bidentate coordination of the PGeP chloridogermyl ligand (see above), the smaller size of carbon monoxide allows a tridentate attachment of the PGeP chloridogermyl ligand in complex 3. Given the non-planarity of the $\mathrm{GeP}_{2} \mathrm{Ir}$ atom grouping in $\mathbf{3}$, the coordination 
type of its PGeP ligand can be referred to as "tripodal" rather than as "pincer". The stability of complex 3 towards CO loss confirms the higher disposition of iridium(I), in comparison to rhodium(I), to be pentacoordinate, since the reaction of the rhodium cod complex $\left[\mathrm{Rh}\left\{\kappa^{2} G e, P\right.\right.$ $\left.\mathrm{GeCl}\left(\mathrm{NCH}_{2} \mathrm{P}^{t} \mathrm{Bu}_{2}\right)_{2} \mathrm{C}_{6} \mathrm{H}_{4}\right\}\left(\eta^{4}\right.$-cod)] with $\mathrm{CO}$ gives a square-planar monocarbonyl PGeP pincer derivative. ${ }^{15}$

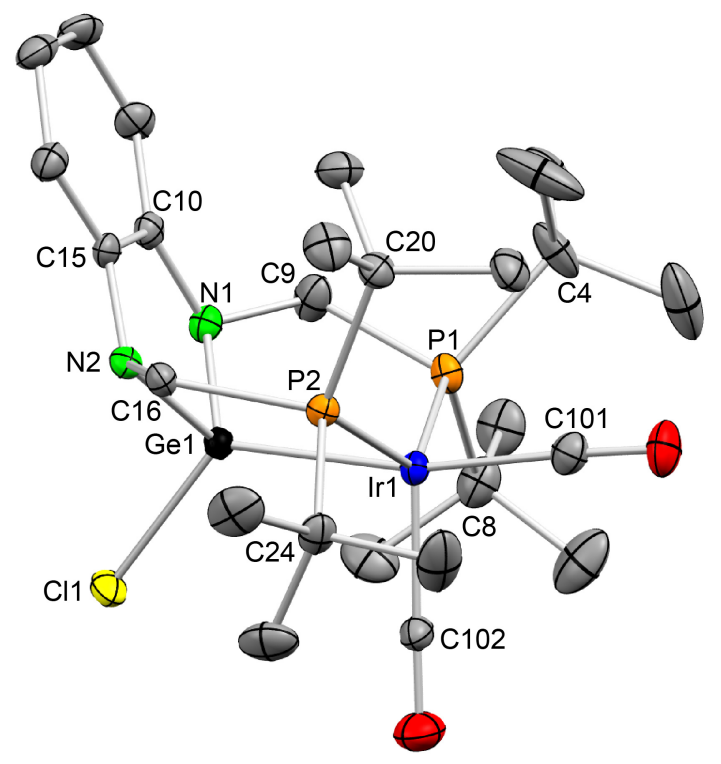

Figure 4. XRD molecular structure of complex 3 (30\% displacement ellipsoids; $\mathrm{H}$ atoms omitted for clarity). Only one of the two analogous molecules found in the asymmetric unit is shown. Selected bond lengths $(\AA)$ and angles $\left(^{\circ}\right)$ : Ir1-C101 1.897(5), Ir1-C102 1.903(5), Ir1-P1 2.388(1), Ir1-P2 2.407(1), Ir1-Ge1 2.3880(5), Ge1-N1 1.865(4), Ge1-N2 1.856(4), Ge1-Cl1 2.203(1), P1-C4 1.889(6), P1-C8 1.899(6), P1-C9 1.880(5), P2-C16 1.899(5), P2-C24 1.900(5), P2-C20 1.908(5), N1-C9 1.454(7), N1-C10 1.399(6), N2-C15 1.402(6), N2-C16 1.454(6), C10-C15 1.415(7); C101-Ir1-P1 96.4(2), C101-Ir1-P2 95.6(2), C101-Ir1-Ge1 167.8(2), C101-Ir1-C102 97.2(2), C102-Ir1P1 110.3(2), C102-Ir1-P2 112.3(2), C102-Ir1-Ge1 95.0(2), P1-Ir1-P2 133.66(4), P1-Ir1-Ge1 79.41(3), P2-Ir1-Ge1 79.63(3), N1-Ge1-N2 91.5(2), N1-Ge1-Cl1 107.5(1), N2-Ge1-Cl1 104.3(1), N1-Ge1-Ir1 112.0(1), N2-Ge1-Ir1 113.5(1), Cl1-Ge1-Ir1 123.22(4).

Scheme 3. Synthesis of Complex 4

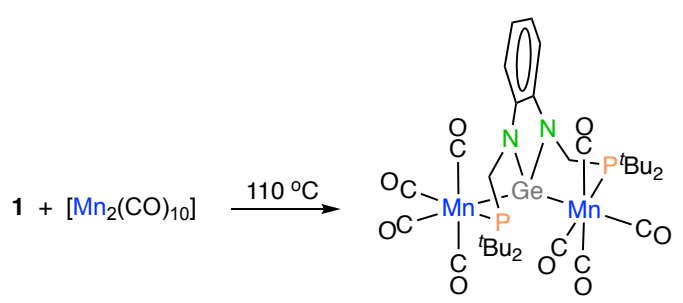

(4)

Reaction of Germylene 1 with $\left[\mathbf{M n}_{2}(\mathbf{C O})_{10}\right]$. The binuclear manganese(I) complex $\left[\mathrm{Mn}_{2}\left\{\mu-\kappa^{3} P, G e, P-\mathrm{Ge}\left(\mathrm{NCH}_{2} \mathrm{P}^{t} \mathrm{Bu}_{2}\right)_{2} \mathrm{C}_{6} \mathrm{H}_{4}\right\}(\mathrm{CO})_{8}\right]$ (4) was obtained from a reaction in which a $1: 1$ mixture of $\left[\mathrm{Mn}_{2}(\mathrm{CO})_{10}\right]$ and germylene 1 was heated in toluene at reflux temperature for $4 \mathrm{~h}$ 
(Scheme 3). Mixtures of products that slowly evolved toward complex 4 were observed at shorter reaction times when the reaction was monitored by IR spectroscopy. After $4 \mathrm{~h}$, the reaction mixture, which contained no $\left[\mathrm{Mn}_{2}(\mathrm{CO})_{10}\right]$, did not change with time and complex 4 was isolated in $56 \%$ yield after a chromatographic separation. The mass spectrum of $\mathbf{4}$ displayed the molecular ion, confirming its binuclear formulation. Its most informative NMR spectrum was the ${ }^{31} \mathrm{P}\left\{{ }^{1} \mathrm{H}\right\}$, which contained only one (rather broad) resonance a high chemical shift of ( $\delta=142.7 \mathrm{ppm}$ in $\mathrm{CD}_{2} \mathrm{Cl}_{2}$ ), indicating that both $\mathrm{P}$ atoms are related by a symmetry element and that they are coordinated to manganese (whose only natural isotope, ${ }^{55} \mathrm{Mn}$, has a nuclear spin of $I=5 / 2$ and a quadrupolar moment, provoking broad NMR signals) in a strained arrangement (high chemical shift, see above).

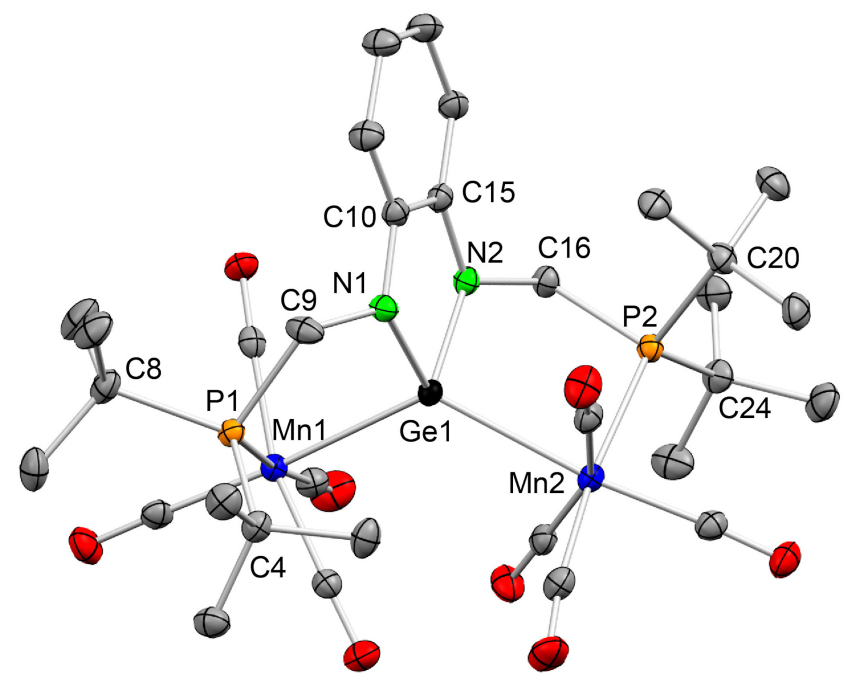

Figure 5. XRD molecular structure of complex 4 (35\% displacement ellipsoids; H atoms omitted for clarity). Selected interatomic distances $(\AA)$ and angles $\left({ }^{\circ}\right)$ : Mn1 $\cdots$ Mn2 4.5162(5), Mn1-Ge1 2.5127(5), Mn1-P1 2.3801(8), Mn2-Ge1 2.5615(5), Mn2-P2 2.3817(8), Ge1-N1 1.903(2), Ge1-N2 1.897(2), P1-C4 1.894(3), P1-C8 1.908(3), P1-C9 1.864(3), P2-C16 1.869(3), P2-C20 1.907(3), P2-C24 1.907(3), N1-C9 1.445(4), N1-C10 1.403(4), N2-C15 1.393(4), N2-C16 1.449(4), C10-C15 1.418(4); N1-Ge1-N2 85.4(1), N1-Ge1-Mn1 97.48(7), N2-Ge1-Mn1 117.54(7), N1-Ge1-Mn2 124.55(8), N2-Ge1-Mn2 99.99(7), Mn1-Ge1-Mn2 125.82(2).

The XRD structure of complex 4 (Figure 5) confirmed the insertion of the Ge atom of germylene 1 into the $\mathrm{Mn}-\mathrm{Mn}$ bond of the original dimanganese(0) reagent and that each phosphane fragment is attached to a $\mathrm{Mn}(\mathrm{CO})_{4}$ unit, resulting in a binuclear complex of approximate (non-crystallographic) $C_{2}$ symmetry, with no metal-metal bond (the $\mathrm{Mn} \cdots \mathrm{Mn}$ distance is $4.5162(5) \AA)$, and with both Mn atoms in an octahedral ligand environment. Some germylene-bridged dimanganese complexes are known, but they have not been prepared by 
germylene-insertion into $\mathrm{Mn}-\mathrm{Mn}$ bonds. ${ }^{22}$ Although the insertion of non-donor-stabilized germylenes into other metal-metal bonds has been previously observed, ${ }^{15,23}$ the only hitherto reported complex that is structurally related to compound $\mathbf{4}$ is the dicobalt derivative $\left[\mathrm{Co}_{2}\left\{\mu-\kappa^{3} P, G e, P-\mathrm{Ge}\left(\mathrm{NCH}_{2} \mathrm{P}^{t} \mathrm{Bu}_{2}\right)_{2} \mathrm{C}_{6} \mathrm{H}_{4}\right\}(\mathrm{CO})_{6}\right]$, in which each $\mathrm{Co}$ atom is in a trigonal bipyramidal environment. ${ }^{15}$

Reaction of Germylene 1 with $\left[\operatorname{RuHCl}(\mathrm{CO})\left(\mathbf{P}^{i} \mathbf{P r}_{3}\right)_{2}\right]$. The coordinatively unsaturated ruthenium(II) complex $\left[\mathrm{RuHCl}(\mathrm{CO})\left(\mathrm{P}^{i} \mathrm{Pr}_{3}\right)_{2}\right]$, which has already shown a rich derivative chemistry, ${ }^{24}$ reacted readily with germylene $\mathbf{1}$ to give $\left[\operatorname{RuHCl}(\mathrm{CO})\left\{\kappa^{2} G e, P\right.\right.$ $\left.\left.\mathrm{Ge}\left(\mathrm{NCH}_{2} \mathrm{P}^{t} \mathrm{Bu}_{2}\right)_{2} \mathrm{C}_{6} \mathrm{H}_{4}\right\}\left(\mathrm{P}^{i} \mathrm{Pr}_{3}\right)\right]$ (5) and free tris(isopropyl)phosphane (Scheme 4). Its spectroscopic data indicated the absence of any symmetry, that the complex maintains the original hydride $\left(\delta_{\mathrm{H}}=\right.$ $-8.73 \mathrm{ppm}\left(\mathrm{dd}, J_{\mathrm{HP}}=21.6\right.$ and $\left.\left.16.3 \mathrm{~Hz}\right)\right)$ and carbonyl $\left(v_{\mathrm{CO}}=1916(\mathrm{~s}) \mathrm{cm}^{-1}\right)$ ligands, and that two of its three phosphane groups $\left(\delta_{\mathrm{P}}=99.9(\mathrm{~d}), 66.2(\mathrm{~d}), 16.0(\mathrm{~s}) \mathrm{ppm}\right)$ are strongly coupled to each other $\left(J_{\mathrm{PP}}=243.0 \mathrm{~Hz}\right)$, suggesting a mutual trans arrangement, but they did not help to unambiguously establish its molecular structure, which was determined by XRD (Figure 6).

Scheme 4. Synthesis of Complex 5

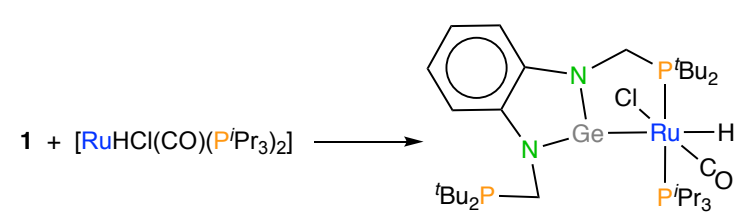

(5) 


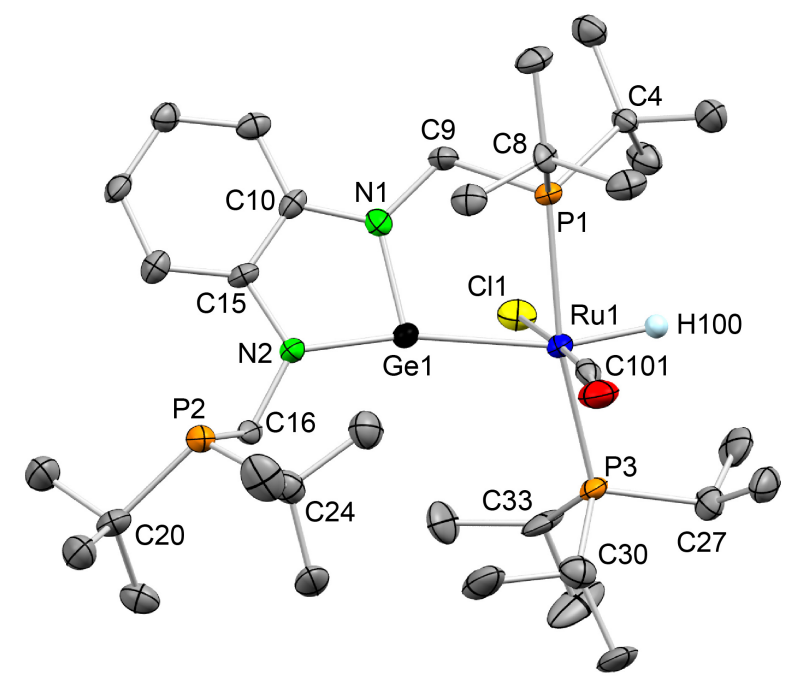

Figure 6. XRD molecular structure of complex 5 (35\% displacement ellipsoids; $H$ atoms, except the hydride ligand, omitted for clarity). Selected bond lengths ( $\AA$ ) and angles $\left({ }^{\circ}\right)$ : Ru1-C101 1.83(1), Ru1-Cl1 2.498(3), Ru1-P1 2.413(2), Ru1-P3 2.386(2), Ru1-Ge1 2.434(1), Ge1-N1 1.838(8), Ge1-N2 1.838(7), P1-C4 1.912(9), P1-C8 1.88(1), P1-C9 1.857(9), P2-C16 1.88(1), P2-C20 1.92(1), P2-C24 1.89(1), P3-C27 1.86(1), P3-C30 1.87(1), P3-C33 1.85(1), N1-C9 1.45(1), N1-C10 1.38(1), N2-C15 1.41(1), N2-C16 1.48(1), C10-C15 1.41(1); P1-Ru1-Ge1 81.06(6), P1-Ru1-Cl1 86.01(8), P1-Ru1-C101 95.9(3), P1-Ru1-P3 168.85(9), P3-Ru1-Ge1 108.11(7), P3-Ru1Cl1 89.42(8), P3-Ru1-C101 89.0(3), Cl1-Ru1-Ge1 79.59(7), Cl1-Ru1-C101 177.3(3), C101-Ru1-Ge1 98.8(3), N1Ge1-N2 86.2(3), N1-Ge1-Ru1 106.1(2), N2-Ge1-Ru1 166.5(2).

Remarkably, in contrast with our initial expectation, compound $\mathbf{5}$ does not contain a chloridogermyl moiety. In fact, it is the first transition metal derivative of compound $\mathbf{1}$ to have the germylene moiety not inserted into $\mathrm{M}-\mathrm{M}$ or $\mathrm{M}-\mathrm{X}(\mathrm{M}=$ transition metal; $\mathrm{X}=$ halogen $)$ bonds. Figure 6 shows that compound $\mathbf{5}$ is a hexacoordinate ruthenium(II) complex in which germylene $\mathbf{1}$ chelates the metal atom through the Ge atom and the $\mathrm{P}$ atom of one of its phosphane groups. As suggested by the ${ }^{31} \mathrm{P}\left\{{ }^{1} \mathrm{H}\right\}$ and ${ }^{1} \mathrm{H}$ NMR spectra, the two coordinated phosphane groups are trans to each other and cis to the hydride ligand, which is trans to the germylene moiety. The Ge,Pchelating attachment of ligand $\mathbf{1}$ to the $\mathrm{Ru}$ atom and the short length of the $\mathrm{CH}_{2} \mathrm{P}^{\prime} \mathrm{Bu}_{2}$ arms do not allow the germylene fragment to coordinate in the expected symmetrical manner, provoking the GeNCPRu ring to be severely strained. Thus, (a) although the Ru atom is in the plane of the 2germabenzimidazol-2-ylidene moiety, it is almost aligned with a Ge-N bond, Ru1-Ge1-N2 166.5(2) ${ }^{\circ}$, with the Ge atom being in an unusual (almost) T-shaped environment; (b) the Ru1-P1 distance, 2.413(2) $\AA$, is notably longer than the Ru1-P3 distance, 2.386(2) $\AA$; and (c) the Ru-Ge bond length, 2.434(1) $\AA$, which cannot be compared with that of any ruthenium complex having a terminal non-donor-stabilized $\mathrm{N}$-heterocyclic germylene ligand (such a complex has never been reported), is also much longer than that of $\left[\mathrm{RuCl}\left\{\mathrm{K}^{3} P, G e, P-\mathrm{GeCl}\left(\mathrm{C}_{6} \mathrm{H}_{4} \mathrm{PPh}_{2}\right)_{2}\right\}\left(\mathrm{PPh}_{3}\right)\right], 2.3906(5)$ 
$\AA$, which contains a $P, G e, P$-tripodal chloridogermyl ligand. ${ }^{25}$ The very wide Ru1-Ge1-N2 angle of complex 5, 166.5(2) ${ }^{\circ}$, is noteworthy because a search at the Cambridge Structural Database has revealed that the widest angle hitherto reported around a tricoordinate $\mathrm{Ge}$ atom is $159.8(1)^{\circ}$, found in $\left[\mathrm{WHCl}\left\{\kappa^{2} G e, P-\mathrm{Ge}\left(\mathrm{CH}_{2} \mathrm{PMe}_{2}\right) \mathrm{Ar}\right\}\left(\mathrm{PMe}_{3}\right)_{3}\right]\left(\mathrm{Ar}=2,6-(\text { trip })_{2} \mathrm{C}_{6} \mathrm{H}_{3}\right)$; trip = 2,4,6- $\left.{ }^{i} \mathrm{Pr}_{3} \mathrm{C}_{6} \mathrm{H}_{2}\right)$, which also features a chelating germylene-phosphane ligand. ${ }^{26}$

As the asymmetric coordination of the germylene moiety of complex $\mathbf{5}$ differs considerably from the symmetric one found for other non-donor-stabilized germylenes, such $\mathrm{GeCl}_{2},{ }^{27}$ $\mathrm{Ge}\left\{\mathrm{N}\left(\mathrm{SiMe}_{3}\right)_{2}\right\}_{2},{ }^{19,23 \mathrm{~b}, 28}$ and some cyclic germylenes, ${ }^{27 b, 29}$ when they act as terminal ligands, we decided to undertake a molecular orbital study to investigate the bonding between the $\mathrm{Ge}$ and $\mathrm{Ru}$ atoms of complex 5. The principal molecular orbital responsible for the Ge-Ru bond (NBO analysis) is the HOMO-86 (Figure 7), which has $\sigma$ character and its energy $(-16.65 \mathrm{eV})$ is well below that of the HOMO $(-7.56 \mathrm{eV})$. The large contribution of the undirected (spherical shape) Ge $4 \mathrm{~s}$ atomic orbital to the HOMO-86 orbital of compound 5 (the composition of this orbital is given in the caption of Figure 7) implies that the overlap of the Ge lone pair with the appropriate metal orbital should be little affected by the asymmetric disposition of the $\mathrm{Ru}$ atom with respect to the germylene moiety. In fact, the very low energy of the HOMO-86 orbital indicates that this overlap is quite efficient. It is also notable that germylene $\mathbf{1}$ does not behave as a $\pi$-acceptor ligand in complex $\mathbf{5}$, since no bonding molecular orbitals displaying $\pi$-type overlaps between the Ge and $\mathrm{Ru}$ atoms have been found. The long Ru-Ge bond length, 2.434(1) $\AA$, should be consequence of (a) the large contribution of the $\mathrm{Ge} 4 \mathrm{~s}$ atomic orbital to the Ru-Ge bond (an hybrid $\mathrm{sp}^{2}$ orbital would lead to a more efficient $\sigma$-overlap than an s orbital) and (b) the absence of Ru to Ge $\pi$-back bonding. 


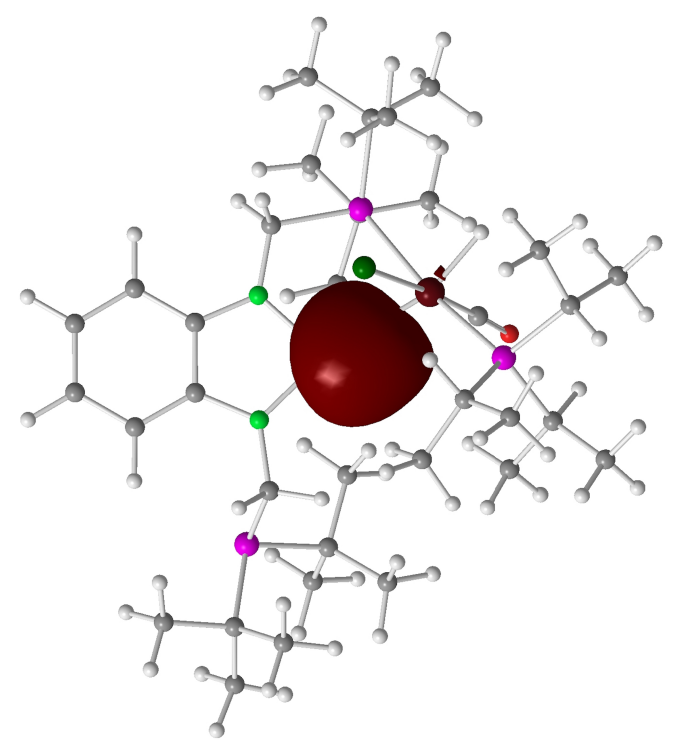

Figure 7. Principal molecular orbital (HOMO-86) responsible for the Ge- Ru bond of complex 5. Its composition is $69.32 \%$ Ge $(81.45 \%$ s, $18.54 \%$ p, $0.01 \%$ d) and $30.68 \%$ Ru (18.00\% s, $61.00 \%$ p, $21.00 \%$ d).

Considering the possibility of inducing an intramolecular rearrangement of complex 5 involving the insertion of the germylene moiety of into the $\mathrm{Ru}-\mathrm{Cl}$ or $\mathrm{Ru}-\mathrm{H}$ bond, we heated at 100 ${ }^{\circ} \mathrm{C}$ a toluene solution of complex $\mathbf{5}$, but in all instances (various reaction times) we got a mixture of products ( ${ }^{31} \mathrm{P}$ NMR analysis) that we could not separate and characterize.

\section{CONCLUDING REMARKS}

An XRD study has established that the structure of the only hitherto known pincer-type diphosphane-germylene $\mathrm{Ge}\left(\mathrm{NCH}_{2} \mathrm{P}^{t} \mathrm{Bu}_{2}\right)_{2} \mathrm{C}_{6} \mathrm{H}_{4}$ (1) is that previously predicted by DFT methods, ${ }^{15,17}$ which indicated that the most stable conformation of the molecule has the lone pairs of both $\mathrm{P}$ atoms weakly interacting with empty orbitals mainly located on the Ge atom.

The isolation of compounds $\mathbf{2}$ and $\mathbf{4}$ has proven the propensity of the Ge atom of $\mathbf{1}$ to get inserted into inorganic $\sigma$-bonds, such as $\mathrm{Ir}-\mathrm{Cl}$ (2) and $\mathrm{Mn}-\mathrm{Mn}$ (4). The chloridogermyl (2) or germylene (4) moieties of these reaction products are additionally attached to the metal atoms through one (2) or two (4) of their phosphane groups. The short distance found between the Ge atom and the pendant phosphane group $\mathrm{P}$ atom of complex $\mathbf{2}$ has been rationalized by DFT calculations. The synthesis of the trigonal-bipyramidal dicarbonyl derivative $\mathbf{3}$ demonstrates that the PGeP chloridogermyl ligand of complex 2 can also act as a $P, G e, P$-tripodal ligand. 
The reaction that led to complex $\mathbf{5}$, in which germylene $\mathbf{1}$ is $G e, P$-chelated to the ruthenium atom, is the first one to render a transition metal derivative that does not arise from an insertion process but from a simple $G e, P$-chelation of germylene $\mathbf{1}$ to a metal atom. In complex $\mathbf{5}$, the short length of its coordinated $\mathrm{CH}_{2} \mathrm{P}^{i} \mathrm{Pr}_{2}$ arm provokes the $\mathrm{Ge}$ atom to be in an uncommon T-shaped environment. A molecular orbital analysis of complex $\mathbf{5}$ has shown that the germylene moiety mainly uses its non-directional Ge 4 s orbital for the bonding with the Ru atom.

This contribution, in conjunction with previous papers dealing with the reactivity of the PGeP pincer-type germylene 1 with rhodium, ${ }^{15}$ cobalt, ${ }^{15}$ and group 10 metal complexes, ${ }^{16}$ helps demonstrate that transition metal complexes containing PGeP pincer germyl or germylene ligands can be prepared directly from the PGeP germylene, also opening up the possibility to explore in a near future the involvement of these complexes in catalytic adventures.

\section{EXPERIMENTAL SECTION}

General Procedures. Solvents were dried over appropriate desiccating reagents and were distilled under argon immediately before use. All reactions were carried out under argon in a dry glovebox or using either Schlenk-vacuum line techniques. Published procedures were followed to prepare germylene $1,{ }^{15}\left[\operatorname{Ir}_{2}(\mu-\mathrm{Cl})_{2}\left(\eta^{4}-\operatorname{cod}\right)_{2}\right],{ }^{30}$ and $\left[\mathrm{RuHCl}(\mathrm{CO})\left(\mathrm{P}^{i} \mathrm{Pr}_{3}\right)_{2}\right] .{ }^{31}$ All remaining reagents were purchased from commercial sources. The reaction products were vacuum-dried for several hours prior to being weighted and analyzed. IR spectra were recorded in a Perkin-Elmer Paragon 1000 spectrophotometer, using solution cells equipped with $\mathrm{CaF}_{2}$ windows. NMR spectra were run on Bruker DPX-300 and NAV-400 instruments, using as standards the residual protic solvent resonance for ${ }^{1} \mathrm{H}\left[\delta\left(\mathrm{C}_{6} \mathrm{HD}_{5}\right)=7.16 \mathrm{ppm} ; \delta\left(\mathrm{CHDCl}_{2}\right)=5.32 \mathrm{ppm}\right]$, the solvent resonance for ${ }^{13} \mathrm{C}$ $\left[\delta\left(C_{6} \mathrm{D}_{6}\right)=128.4 \mathrm{ppm} ; \delta\left(C \mathrm{D}_{2} \mathrm{Cl}_{2}\right)=54.0 \mathrm{ppm}\right]$, and aqueous $85 \% \mathrm{H}_{3} \mathrm{PO}_{4}$ as external reference for ${ }^{31} \mathrm{P}\left[\delta\left(\mathrm{H}_{3} \mathrm{PO}_{4}\right)=0.0 \mathrm{ppm}\right] ;{ }^{13} \mathrm{C}$ assignments were done with the help of DEPT-135 spectra. Microanalyses were obtained with a Perkin-Elmer 2400 microanalyzer. Mass spectra (LRMS) were obtained with a Bruker Impact II mass spectrometer operating in the ESI-Q-ToF positive mode; data given refer to the most probable isotopomer.

$\left[\operatorname{Ir}\left\{\kappa^{2} G e, P-G e C l\left(\mathrm{NCH}_{2} \mathbf{P}^{t} \mathbf{B u}_{2}\right)_{2} \mathbf{C}_{6} \mathbf{H}_{4}\right\}\left(\eta^{4}-\operatorname{cod}\right)\right](2):$ In a dry box, toluene (3 mL) was added to a vial charged with germylene $1(58 \mathrm{mg}, 0.12 \mathrm{mmol})$ and $\left[\operatorname{Ir}_{2}(\mu-\mathrm{Cl})_{2}\left(\eta^{4}-\mathrm{cod}\right)_{2}\right](40 \mathrm{mg}$, $0.06 \mathrm{mmol}$ ). The mixture was stirred at room temperature for $30 \mathrm{~min}$. The initial orange color 
changed rapidly to dark red. The solvents were removed under reduced pressure and the residue was washed with hexanes $(5 \mathrm{~mL})$ and vacuum-dried to give 2 as a red solid (80 $\mathrm{mg}, 82 \%)$. Anal. (\%) calcd for $\mathrm{C}_{32} \mathrm{H}_{56} \mathrm{ClGeIrN}_{2} \mathrm{P}_{2}\left(M_{\mathrm{W}}=831.05 \mathrm{Da}\right)$ : C 46.25, $\mathrm{H}$ 6.79, $\mathrm{N}$ 3.37; found: C 46.66, $\mathrm{H}$ 6.82, N 3.25. (+)-ESI LRMS: $m / z=$ found: 859 ; calcd for $[M-\mathrm{Cl}+2 \mathrm{MeOH}]^{+}: 859.33 .{ }^{1} \mathrm{H} \mathrm{NMR}$ $\left(\mathrm{CD}_{2} \mathrm{Cl}_{2}, 300.1 \mathrm{MHz}, 293 \mathrm{~K}\right): \delta=6.75-6.60\left(\mathrm{~m}, 4 \mathrm{H}, 4 \mathrm{CH}\right.$ of $\left.\mathrm{C}_{6} \mathrm{H}_{4}\right), 5.29(\mathrm{~m}, \mathrm{br}, 2 \mathrm{H}, 2 \mathrm{CH}$ of cod), 5.19 (s, br, $2 \mathrm{H}, 2 \mathrm{CH}$ of cod), $3.72\left(\mathrm{~m}, 1 \mathrm{H}, 1 \mathrm{CH}\right.$ of $\left.\mathrm{PCH}_{2}\right), 3.59\left(\mathrm{~m}, 1 \mathrm{H}, 1 \mathrm{CH}\right.$ of $\left.\mathrm{PCH}_{2}\right)$, 3.29 (m, br, $1 \mathrm{CH}$ of $\left.\mathrm{PCH}_{2}\right), 3.06\left(\mathrm{~m}, 1 \mathrm{H}, 1 \mathrm{CH}\right.$ of $\left.\mathrm{PCH}_{2}\right), 2.25-175\left(\mathrm{~m}, \mathrm{br}, 8 \mathrm{H}\right.$ of $4 \mathrm{CH}_{2}$ of cod), $1.38\left(\mathrm{~d}, J_{\mathrm{HP}}=11.6 \mathrm{~Hz}, 9 \mathrm{H}, 3 \mathrm{CH}_{3}\right.$ of $\left.{ }^{t} \mathrm{Bu}\right), 1.29\left(\mathrm{~d}, J_{\mathrm{HP}}=12.1 \mathrm{~Hz}, 9 \mathrm{H}, 3 \mathrm{CH}_{3}\right.$ of $\left.{ }^{t} \mathrm{Bu}\right), 1.19\left(\mathrm{~d}, J_{\mathrm{HP}}\right.$ $=12.2 \mathrm{~Hz}, 9 \mathrm{H}, 3 \mathrm{CH}_{3}$ of $\left.{ }^{t} \mathrm{Bu}\right), 1.13\left(\mathrm{~d}, J_{\mathrm{HP}}=10.7 \mathrm{~Hz}, 9 \mathrm{H}, 3 \mathrm{CH}_{3}\right.$ of $\left.{ }^{t} \mathrm{Bu}\right), \mathrm{ppm} .{ }^{13} \mathrm{C}\left\{{ }^{1} \mathrm{H}\right\} \mathrm{NMR}$ $\left(\mathrm{CD}_{2} \mathrm{Cl}_{2}, 100.6 \mathrm{MHz}, 293 \mathrm{~K}\right): \delta=143.9\left(\mathrm{~d}, J_{\mathrm{CP}}=1.4 \mathrm{~Hz}, C\right.$ of $\left.\mathrm{C}_{6} \mathrm{H}_{4}\right), 140.4\left(\mathrm{~d}, J_{\mathrm{CP}}=1.1 \mathrm{~Hz}, C\right.$ of $\left.\mathrm{C}_{6} \mathrm{H}_{4}\right), 117.5\left(\mathrm{~s}, \mathrm{CH}\right.$ of $\left.\mathrm{C}_{6} \mathrm{H}_{4}\right), 116.8\left(\mathrm{~s}, \mathrm{CH}\right.$ of $\left.\mathrm{C}_{6} \mathrm{H}_{4}\right), 109.5\left(\mathrm{~s}, \mathrm{CH}\right.$ of $\left.\mathrm{C}_{6} \mathrm{H}_{4}\right), 108.8\left(\mathrm{~s}, \mathrm{CH}\right.$ of $\left.\mathrm{C}_{6} \mathrm{H}_{4}\right)$, $81.5\left(\mathrm{~m}, \mathrm{br}, 4 \mathrm{CH}\right.$ of cod), $42.1\left(\mathrm{~d}, J_{\mathrm{CP}}=16.0 \mathrm{~Hz}, 1 \mathrm{C}\right.$ of $\left.{ }^{t} \mathrm{Bu}\right), 38.8\left(\mathrm{~s}, \mathrm{br}, \mathrm{CH}_{2}\right.$ of $\left.\mathrm{PCH}_{2}\right), 36.6(\mathrm{~d}$, $J_{\mathrm{CP}}=14.6 \mathrm{~Hz}, 1 C$ of $\left.{ }^{t} \mathrm{Bu}\right), 33.5\left(\mathrm{~d}, J_{\mathrm{CP}}=34.2 \mathrm{~Hz}, C_{2}\right.$ of $\left.\mathrm{PCH}_{2}\right), 33.0-32.0\left(\mathrm{~m}, 2 C\right.$ of $t \mathrm{Bu}+C \mathrm{H}_{2}$ of $\mathrm{PCH}_{2}+4 \mathrm{CH}_{2}$ of cod), 30.8-29.5 (m, $12 \mathrm{CH}_{3}$ of $\left.4{ }^{t} \mathrm{Bu}\right) \mathrm{ppm} .{ }^{31} \mathrm{P}\left\{{ }^{1} \mathrm{H}\right\} \mathrm{NMR}\left(\mathrm{C}_{6} \mathrm{D}_{6}, 162.0 \mathrm{MHz}\right.$, $293 \mathrm{~K}): \delta=75.9(\mathrm{~s}), 29.7$ (s) ppm.

$\left[\operatorname{Ir}\left\{\kappa^{3} P, G e, P-G e C l\left(\mathrm{NCH}_{2} \mathbf{P}^{t} \mathbf{B u}_{2}\right)_{2} \mathrm{C}_{6} \mathrm{H}_{4}\right\}(\mathrm{CO})_{2}\right](3)$ : In a Schlenk tube, carbon monoxide was bubbled for $10 \mathrm{~min}$ through a toluene $(4 \mathrm{~mL})$ solution of complex $\mathbf{3}$ (42 $\mathrm{mg}, 0.05 \mathrm{mmol})$. The color changed from dark orange to yellow. The resulting solution as evaporated to dryness to give 3 as a yellow solid (38 mg, $98 \%$ ). Anal. (\%) calcd. for $\mathrm{C}_{26} \mathrm{H}_{44} \mathrm{ClGeIrN}_{2} \mathrm{O}_{2} \mathrm{P}_{2}\left(M_{\mathrm{W}}=778.88 \mathrm{Da}\right)$ : C 40.09, H 5.69, N 3.60; found: C, 40.16; H, 5.77; N, 3.55. (+)-ESI LRMS: $m / z=$ found: 751; calcd for $[M-\mathrm{CO}+\mathrm{H}]^{+}:$751.15. IR (toluene): $v_{\mathrm{CO}}=2001(\mathrm{vs}), 1956$ (vs) $\mathrm{cm}^{-1} .{ }^{1} \mathrm{H}$ NMR $\left(\mathrm{C}_{6} \mathrm{D}_{6}, 400.1\right.$ $\mathrm{MHz}, 293 \mathrm{~K}): \delta=6.92\left(\mathrm{~m}, 2 \mathrm{H}, 2 \mathrm{CH}\right.$ of $\left.\mathrm{C}_{6} \mathrm{H}_{4}\right), 6.85\left(\mathrm{~m}, 2 \mathrm{H}, 2 \mathrm{CH}\right.$ of $\left.\mathrm{C}_{6} \mathrm{H}_{4}\right), 3.39(\mathrm{~m}, 2 \mathrm{H}, 2 \mathrm{CH}$ of $\left.\mathrm{PCH}_{2}\right), 2.95\left(\mathrm{~m}, 2 \mathrm{H}, 2 \mathrm{CH}\right.$ of $\left.\mathrm{PCH}_{2}\right), 1.21\left(\mathrm{~m}, 18 \mathrm{H}, 6 \mathrm{CH}_{3}\right.$ of $\left.2{ }^{t} \mathrm{Bu}\right), 0.79\left(\mathrm{~m}, 18 \mathrm{H}, 6 \mathrm{CH}_{3}\right.$ of 2 $\left.{ }^{t} \mathrm{Bu}\right)$ ppm. ${ }^{13} \mathrm{C}\left\{{ }^{1} \mathrm{H}\right\} \mathrm{NMR}\left(\mathrm{C}_{6} \mathrm{D}_{6}, 100.6 \mathrm{MHz}, 293 \mathrm{~K}\right): \delta=187.1\left(\mathrm{t}, J_{\mathrm{CP}}=9.1 \mathrm{~Hz}, C O\right), 178.6\left(\mathrm{t}, J_{\mathrm{CP}}\right.$ $=32.2 \mathrm{~Hz}, \mathrm{CO}), 146.8\left(\mathrm{~s}, 2 \mathrm{C}\right.$ of $\left.\mathrm{C}_{6} \mathrm{H}_{4}\right), 120.0\left(\mathrm{~s}, 2 \mathrm{CH}\right.$ of $\left.\mathrm{C}_{6} \mathrm{H}_{4}\right), 115.9\left(\mathrm{~s}, 2 \mathrm{CH}\right.$ of $\left.\mathrm{C}_{6} \mathrm{H}_{4}\right), 49.0(\mathrm{~s}$, $2 \mathrm{CH}_{2}$ of $\left.2 \mathrm{PCH}_{2}\right), 38.7\left(\mathrm{~s}, 2 \mathrm{C}\right.$ of $\left.2{ }^{t} \mathrm{Bu}\right), 36.8\left(\mathrm{~s}, 2 \mathrm{C}\right.$ of $\left.2{ }^{t} \mathrm{Bu}\right), 30.4\left(\mathrm{~s}, 6 \mathrm{CH}_{3}\right.$ of $\left.2{ }^{t} \mathrm{Bu}\right), 29.8(\mathrm{~s}, 6$ $\mathrm{CH}_{3}$ of $\left.2{ }^{t} \mathrm{Bu}\right) \mathrm{ppm} .{ }^{31} \mathrm{P}\left\{{ }^{1} \mathrm{H}\right\} \mathrm{NMR}\left(\mathrm{C}_{6} \mathrm{D}_{6}, 162.0 \mathrm{MHz}, 293 \mathrm{~K}\right): \delta=116.3$ (s) ppm.

$\left[\mathrm{Mn}_{2}\left\{\mu-\kappa^{3} P, G e, P-G e\left(\mathrm{NCH}_{2} \mathbf{P}^{t} \mathbf{B u}_{2}\right)_{2} \mathbf{C}_{6} \mathbf{H}_{4}\right\}(\mathbf{C O})_{8}\right]$ (4): A Schlenk tube was charged with germylene 1 (40 mg, $0.08 \mathrm{mmol}),\left[\mathrm{Mn}_{2}(\mathrm{CO})_{10}\right](31 \mathrm{mg}, 0.08 \mathrm{mmol})$, and toluene $(5 \mathrm{~mL})$. The yellow solution was stirred at reflux temperature for $4 \mathrm{~h}$. The color changed from yellow to red- 
brown. A flash chromatographic separation $(2 \times 5 \mathrm{~cm}$ silica gel column packed in hexane), eluting with dichloromethane, afforded compound 4 as a red solid (37 mg, $56 \%$ ). Anal. (\%) calcd for $\mathrm{C}_{32} \mathrm{H}_{44} \mathrm{GeMn}_{2} \mathrm{~N}_{2} \mathrm{O}_{8} \mathrm{P}_{2}\left(M_{\mathrm{w}}=829.15 \mathrm{Da}\right)$ : C 46.35, H 5.35, N 3.38; found: C 46.44, H 5.47, N 3.36. (+)-ESI LRMS: $m / z=$ found: 830; calculated for $[M]^{+}: 830.06$. IR (toluene): $v_{\mathrm{CO}}=2050(\mathrm{~m}), 2021$ (s), 1970 (sh), 1964 (s), 1947 (m), 1931 (s) cm ${ }^{-1} .{ }^{1} \mathrm{H}$ NMR $\left(\mathrm{C}_{6} \mathrm{D}_{6}, 300.1 \mathrm{MHz}, 293 \mathrm{~K}\right): \delta=6.84$ (m, $2 \mathrm{H}, 2 \mathrm{CH}$, of $\left.\mathrm{C}_{6} \mathrm{H}_{4}\right), 6.69\left(\mathrm{~m}, 2 \mathrm{H}, 2 \mathrm{CH}\right.$, of $\left.\mathrm{C}_{6} \mathrm{H}_{4}\right), 4.09\left(\mathrm{dd}, J_{\mathrm{HH}}=14.1 \mathrm{~Hz}, J_{\mathrm{HP}}=8.4 \mathrm{~Hz}, 2 \mathrm{H}, 2\right.$ $\mathrm{CH}$ of $\left.\mathrm{PCH}_{2}\right), 3.05\left(\mathrm{dd}, J_{\mathrm{HH}}=14.1 \mathrm{~Hz}, J_{\mathrm{HP}}=10.3 \mathrm{~Hz}, 2 \mathrm{H}, 2 \mathrm{CH}\right.$ of $\left.\mathrm{PCH}_{2}\right), 1.16\left(\mathrm{~d}, J_{\mathrm{HP}}=12.3 \mathrm{~Hz}\right.$, $18 \mathrm{H}, 6 \mathrm{CH}_{3}$ of $\left.2{ }^{t} \mathrm{Bu}\right), 0.93\left(\mathrm{~d}, J_{\mathrm{HP}}=12.5 \mathrm{~Hz}, 18 \mathrm{H}, 6 \mathrm{CH}_{3}\right.$ of $\left.2{ }^{t} \mathrm{Bu}\right) \mathrm{ppm} .{ }^{13} \mathrm{C}\left\{{ }^{1} \mathrm{H}\right\} \mathrm{NMR}\left(\mathrm{CD}_{2} \mathrm{Cl}_{2}\right.$, 100.6 MHz, $293 \mathrm{~K}$ ): $\delta=220.3-214.4$ (m, COs), 146.7 (s, $2 C$ of $\mathrm{C}_{6} \mathrm{H}_{4}$ ), 116.5 (s, $2 \mathrm{CH}$ of $\mathrm{C}_{6} \mathrm{H}_{4}$ ), $109.6\left(\mathrm{~s}, 2 \mathrm{CH}\right.$ of $\left.\mathrm{C}_{6} \mathrm{H}_{4}\right), 41.6\left(\mathrm{~s}\right.$, br, $2 \mathrm{CH}_{2}$ of $\left.2 \mathrm{PCH}_{2}\right), 37.7$ (s, br, $4 C$ of $\left.4{ }^{t} \mathrm{Bu}\right), 30.7\left(\mathrm{~s}, 6 \mathrm{CH}_{3}\right.$ of $\left.2{ }^{t} \mathrm{Bu}\right), 30.3\left(\mathrm{~s}, 6 \mathrm{CH}_{3}\right.$ of $\left.2{ }^{t} \mathrm{Bu}\right) \mathrm{ppm} .{ }^{31} \mathrm{P}\left\{{ }^{1} \mathrm{H}\right\} \mathrm{NMR}\left(\mathrm{CD}_{2} \mathrm{Cl}_{2}, 162.0 \mathrm{MHz}, 293 \mathrm{~K}\right): \delta=142.7$ (s) ppm.

$\left[\mathrm{RuHCl}(\mathrm{CO})\left\{\kappa^{2} G e, P-G e\left(\mathrm{NCH}_{2} \mathbf{P}^{t} \mathbf{B u}_{2}\right)_{2} \mathbf{C}_{6} \mathbf{H}_{4}\right\}\left(\mathbf{P}^{i} \mathbf{P r}_{3}\right)\right](5):$ In a dry box, a vial was charged with germylene $1(173 \mathrm{mg}, 0.35 \mathrm{mmol})$, [RuHCl$\left.(\mathrm{CO})\left(\mathrm{P}^{i} \mathrm{Pr}_{3}\right)_{2}\right](170 \mathrm{mg}, 0.35 \mathrm{mmol})$, and toluene (3 mL). The yellow solution was stirred at room temperature for $1 \mathrm{~h}$ (no color change was observed) and was evaporated to dryness. The residue was washed with hexane $(3 \times 3 \mathrm{~mL})$ and vacuum-dried to give 5 as a yellow solid (209 mg, 73\%). Anal. (\%) calcd for $\mathrm{C}_{34} \mathrm{H}_{66} \mathrm{ClGeN}_{2} \mathrm{OP}_{3} \mathrm{Ru}$ $\left(M_{\mathrm{W}}=820.97 \mathrm{Da}\right): \mathrm{C} 49.74, \mathrm{H}$ 8.10, N 3.41; found: C 49.93, H 8.22, N 3.36. ESI LRMS: no useful spectrum could be obtained. IR (toluene): $v_{\mathrm{CO}}=1916(\mathrm{~s}) \mathrm{cm}^{-1} .{ }^{1} \mathrm{H}$ NMR $\left(\mathrm{C}_{6} \mathrm{D}_{6}, 400.1 \mathrm{MHz}\right.$, $293 \mathrm{~K}): \delta=7.54\left(\mathrm{~m}, 1 \mathrm{H}, 1 \mathrm{CH}\right.$, of $\left.\mathrm{C}_{6} \mathrm{H}_{4}\right), 7.19-7.15\left(\mathrm{~m}, 2 \mathrm{H}, 2 \mathrm{CH}\right.$, of $\mathrm{C}_{6} \mathrm{H}_{4}$, overlapped with the solvent peak), $7.05\left(\mathrm{~m}, 1 \mathrm{H}, 1 \mathrm{CH}\right.$ of $\left.\mathrm{C}_{6} \mathrm{H}_{4}\right), 4.35\left(\mathrm{~d}, J_{\mathrm{HP}}=14.2 \mathrm{~Hz}, 1 \mathrm{H}, 1 \mathrm{CH} \text { of PCH}\right)_{2}, 4.17-3.93$ $\left(\mathrm{m}, 3 \mathrm{H}, 3 \mathrm{CH}\right.$ of $\left.2 \mathrm{PCH}_{2}\right), 2.71\left(\mathrm{~m}, 3 \mathrm{H}, 3 \mathrm{CH}\right.$ of $\left.\mathrm{P}^{i} \mathrm{Pr}_{3}\right), 1.56-1.36\left(\mathrm{~m}, 30 \mathrm{H}, 10 \mathrm{CH}_{3}\right.$ of $\mathrm{P}^{i} \operatorname{Pr}_{3}$ and $\left.{ }^{t} \mathrm{Bu}\right), 1.18-1.09\left(\mathrm{~m}, 24 \mathrm{H}, 8 \mathrm{CH}_{3}\right.$ of $\mathrm{P}^{i} \mathrm{Pr}_{3}$ and $\left.{ }^{t} \mathrm{Bu}\right),-8.73\left(\mathrm{dd}, J_{\mathrm{HP}}=21.6\right.$ and $\left.16.3 \mathrm{~Hz}, 1 \mathrm{H}, \mathrm{Ru} H\right)$ ppm. ${ }^{13} \mathrm{C}\left\{{ }^{1} \mathrm{H}\right\} \operatorname{NMR}\left(\mathrm{C}_{6} \mathrm{D}_{6}, 100.6 \mathrm{MHz}, 293 \mathrm{~K}\right): \delta=142.0\left(\mathrm{~s}, C\right.$ of $\left.\mathrm{C}_{6} \mathrm{H}_{4}\right), 141.7\left(\mathrm{~d}, J_{\mathrm{C}-\mathrm{P}}=10.9 \mathrm{~Hz}\right.$, $C$ of $\left.\mathrm{C}_{6} \mathrm{H}_{4}\right), 119.5\left(\mathrm{~s}, C \mathrm{H}\right.$ of $\left.\mathrm{C}_{6} \mathrm{H}_{4}\right), 117.8\left(\mathrm{~s}, C \mathrm{H}\right.$ of $\left.\mathrm{C}_{6} \mathrm{H}_{4}\right), 111.8\left(\mathrm{~d}, J_{\mathrm{CP}}=7.5 \mathrm{~Hz}, C \mathrm{H}\right.$ of $\left.\mathrm{C}_{6} \mathrm{H}_{4}\right)$, $109.9\left(\mathrm{~s}, \mathrm{CH}\right.$ of $\left.\mathrm{C}_{6} \mathrm{H}_{4}\right), 42.7\left(\mathrm{~d}, J_{\mathrm{CP}}=22.4 \mathrm{~Hz}, \mathrm{CH}_{2}\right.$ of $\left.\mathrm{PCH}_{2}\right), 37.8\left(\mathrm{~d}, J_{\mathrm{CP}}=15.7 \mathrm{~Hz}, C\right.$ of $\left.{ }^{t} \mathrm{Bu}\right)$, $37.4\left(\mathrm{~d}, J_{\mathrm{CP}}=11.8 \mathrm{~Hz}, C\right.$ of $\left.{ }^{t} \mathrm{Bu}\right), 33.4\left(\mathrm{~d}, J_{\mathrm{CP}}=23.8 \mathrm{~Hz}, C \mathrm{H}_{2}\right.$ of $\left.\mathrm{PCH}_{2}\right), 32.4\left(\mathrm{~d}, J_{\mathrm{CP}}=10.1 \mathrm{~Hz}, C\right.$ of $\left.{ }^{t} \mathrm{Bu}\right), 32.2\left(\mathrm{~d}, J_{\mathrm{CP}}=11.4 \mathrm{~Hz}, C\right.$ of $\left.{ }^{t} \mathrm{Bu}\right), 31.5\left(\mathrm{~s}, 3 C \mathrm{H}_{3}\right.$ of $\left.{ }^{t} \mathrm{Bu}\right), 31.0\left(\mathrm{~s}, 3 C \mathrm{H}_{3}\right.$ of $\left.{ }^{t} \mathrm{Bu}\right), 30.2\left(\mathrm{~d}, J_{\mathrm{CP}}=\right.$ $12.9 \mathrm{~Hz}, 3 \mathrm{CH}_{3}$ of $\left.\mathrm{P}^{i} \mathrm{Pr}_{3}\right), 30.0\left(\mathrm{~d}, J_{\mathrm{CP}}=12.5 \mathrm{~Hz}, 3 C \mathrm{H}_{3}\right.$ of $\left.\mathrm{P}^{i} \mathrm{Pr}_{3}\right), 24.3\left(\mathrm{~d}, J_{\mathrm{CP}}=20.2 \mathrm{~Hz}, 3 C \mathrm{H}\right.$ of 
$\left.\mathrm{P}^{i} \mathrm{Pr}_{3}\right), 20.4$ (s, $3 \mathrm{CH}_{3}$ of ${ }^{t} \mathrm{Bu}$ ), $20.0\left(\mathrm{~s}, 3 \mathrm{CH}_{3}\right.$ of $\left.{ }^{t} \mathrm{Bu}\right) \mathrm{ppm} .{ }^{31} \mathrm{P}\left\{{ }^{1} \mathrm{H}\right\} \mathrm{NMR}\left(\mathrm{C}_{6} \mathrm{D}_{6}, 162.0 \mathrm{MHz}, 293\right.$ $\mathrm{K}): \delta=99.9\left(\mathrm{~d}, J_{\mathrm{PP}}=243.0 \mathrm{~Hz}\right), 66.2\left(\mathrm{~d}, J_{\mathrm{PP}}=243.0 \mathrm{~Hz}\right), 16.0(\mathrm{~s}) \mathrm{ppm}$.

X-Ray Diffraction Analyses. Crystals of 1, 2, 3. $\left(\mathrm{C}_{7} \mathrm{H}_{8}\right)_{0.75}, \mathbf{4} \cdot\left(\mathrm{C}_{7} \mathrm{H}_{8}\right)$, and 5 were analyzed by X-ray diffraction. They all were obtained in the drybox by slow evaporation of toluene solutions contained in open vials. Selection of crystal, measurement and refinement data is given in Table S1. Diffraction data were collected on an Oxford Diffraction Xcalibur Onyx Nova single crystal diffractometer with $\mathrm{CuK} \alpha$ radiation. Empirical absorption corrections were applied using the SCALE3 ABSPACK algorithm as implemented in CrysAlisPro RED. ${ }^{32}$ The structures were solved using SIR-97. ${ }^{33}$ Isotropic and full matrix anisotropic least square refinements were carried out using SHELXL. ${ }^{34}$ All non-H atoms were refined anisotropically. $\mathrm{H}$ atoms were set in calculated positions and were refined riding on their parent atoms. The position of the hydride ligand of 5 was calculated with XHYDEX. ${ }^{35}$ The methyls of one tertbutyl group of 2 (C8 is its quaternary carbon) were disordered over two positions with a $68: 32$ occupancy ratio, requiring restraints on the geometrical and thermal parameters. The toluene solvent molecules found in the crystal of $\mathbf{3} \cdot\left(\mathrm{C}_{7} \mathrm{H}_{8}\right)_{0.75}$ were disordered about centers of symmetry and required restraints on their geometrical and thermal parameters. The WINGX program system ${ }^{36}$ was used throughout the structure determinations. The molecular plots were made with MERCURY.${ }^{37}$ CCDC deposition numbers: $1829992(\mathbf{1}), 1829993(\mathbf{2}), 1829994\left(3 \cdot\left(\mathrm{C}_{7} \mathrm{H}_{8}\right)_{0.75}\right), 1829995\left(\mathbf{4} \cdot \mathrm{C}_{7} \mathrm{H}_{8}\right)$ and $1829996(\mathbf{5})$.

Theoretical Calculations. DFT Calculations were carried out using the wB97XD functional, ${ }^{38}$ which includes the second generation of Grimme's dispersion interaction correction ${ }^{39}$ as well as long-range interactions effects. This functional reproduces the local coordination geometry of transition metal compounds very well and it also corrects the systematic overestimation of non-bonded distances seen for all the density functionals that do not include estimates of dispersion. ${ }^{40}$ The Stuttgart-Dresden relativistic effective core potential and the associated basis sets (SDD) were used for the $\mathrm{Ir}^{41}$ and $\mathrm{Ru}$ atoms. ${ }^{42}$ The basis set used for the remaining atoms was the cc-pVDZ. ${ }^{43}$ The stationary points were fully optimized in gas phase and confirmed as energy minima (all positive eigenvalues) by analytical calculation of frequencies. The orbital analysis was carried out within the NBO framework..$^{44}$ All calculations were carried out with the Gaussian09 package. ${ }^{45}$ The atomic coordinates of all the DFT-optimized structures are given in the electronic supplementary information. 


\section{ASSOCIATED CONTENT}

\section{Supporting Information}

The Supporting Information is available free of charge on the ACS Publications website at DOI: 10.1021/acs.organomet.Xxxxxxx.

${ }^{-1} \mathrm{H},{ }^{13} \mathrm{C}\left\{{ }^{1} \mathrm{H}\right\}$, and ${ }^{31} \mathrm{P}\left\{{ }^{1} \mathrm{H}\right\}$ NMR spectra of complexes 2-5 (Figures S1-S4); crystal, measurement and refinement data for the compounds studied by XRD (Table S1) (PDF) -Atomic coordinates for the DFT-optimized structures (XYZ)

\section{Accession Codes}

CCDC 1829992-1829996 contain the supplementary crystallographic data for this paper. These data can be obtained free of charge via www.ccdc.cam.ac.uk/data_request/cif, or by emailing data_request@ccdc.cam.ac.uk, or by contacting The Cambridge Crystallographic Data Centre, 12 Union Road, Cambridge CB2 1EZ, UK; fax: +44 1223336033.

\section{AUTHOR INFORMATION}

\section{Corresponding Author}

*E-mail: jac@uniovi.es

\section{ORCID}

Javier Brugos: 0000-0002-4837-3282

Javier A. Cabeza: 0000-0001-8563-9193

Pablo García-Álvarez: 0000-0002-5024-3874

Enrique Pérez-Carreño: 0000-0001-8042-0678

\section{Notes}

The authors declare no competing financial interest.

\section{ACKNOWLEDGMENTS}

This work has been supported by MINECO-FEDER (CTQ2016-75218-P, MAT2016-78155-C2-1R, RYC2012-10491 and CTQ2016-81797-REDC) and Gobierno del Principado de Asturias (GRUPIN14-009 and GRUPIN14-060) research grants. 


\section{REFERENCES}

(1) Reviews on transition metal chemistry of heavier tetrylenes: (a) Tacke, R.; Ribbeck, T. Bis(amidinato)- and bis(guanidinato)silylenes and silylenes with one sterically demanding amidinato or guanidinato ligand: synthesis and reactivity. Dalton Trans. 2017, 46, 13628-13659. (b) Cabeza, J. A.; García-Álvarez, P.; Polo, D. Intramolecularly Stabilized Heavier Tetrylenes: From Monodentate to Bidentate Ligands. Eur. J. Inorg. Chem. 2016, 10-22. (c) ÁlvarezRodríguez, L.; Cabeza, J. A.; García-Álvarez, P.; Polo, D. The transition-metal chemistry of amidinatosilylenes, -germylenes and -stannylenes. Coord. Chem. Rev. 2015, 300, 1-28. (d) Blom, B.; Stoelzel, M.; Driess, M. New Vistas in N-Heterocyclic Silylene (NHSi) Transition-Metal Coordination Chemistry: Syntheses, Structures and Reactivity towards Activation of Small Molecules. Chem. Eur. J. 2013, 19, 40-62. (e) Baumgartner, J.; Marschner, C. Coordination of non-stabilized germylenes, stannylenes, and plumbylenes to transition metals. Rev. Inorg. Chem. 2014, 34, 119-152. (f) Zabula, A. V.; Hahn, F. E. Mono- and Bidentate Benzannulated NHeterocyclic Germylenes, Stannylenes and Plumbylenes. Eur. J. Inorg. Chem. 2008, 5165-5179.

(g) Leung, W.-P.; Kan, K.-W.; Chong, K.-H. Reactions of some organogermanium(II) chlorides. Coord. Chem. Rev. 2007, 251, 2253-2265. (h) Waterman, R.; Hayes, P. G.; Tilley, T. D. Synthetic Development and Chemical Reactivity of Transition-Metal Silylene Complexes. Acc. Chem. Res. 2007, 40, 712-719. (i) Kühl, O. N-heterocyclic germylenes and related compounds. Coord. Chem. Rev. 2004, 248, 411-427; (j) Okazaki, M.; Tobita, H.; Ogino, H. Reactivity of silylene complexes. Dalton Trans. 2003, 493-506.

(2) (a) Benedek, Z.; Szilvási, T. Theoretical Assessment of Low-Valent Germanium Compounds as Transition Metal Ligands: Can They Be Better than Phosphines or NHCs? Organometallics 2017, 36, 1591-1600. (b) Benedek, Z.; Szilvási, T. Can low-valent silicon compounds be better transition metal ligands than phosphines and NHCs? RSC Adv. 2015, 5, 5077-5086. (c) Cabeza, J. A.; Fernández-Colinas, J. M.; García-Álvarez, P.; Pérez-Carreño, E.; Polo, D. Amidinatogermylene Derivatives of Ruthenium Carbonyl: New Insights into the Reactivity of $\left[\mathrm{Ru}_{3}(\mathrm{CO})_{12}\right]$ with Two-Electron-Donor Reagents of High Basicity. Inorg. Chem. 2015, 54, 2983-2994. (d) Cabeza, J. A.; García-Álvarez, P.; Pérez-Carreño, E.; Polo, D. Ring Opening and Bidentate Coordination of Amidinate Germylenes and Silylenes on Carbonyl 
Dicobalt Complexes: The Importance of a Slight Difference in Ligand Volume. Chem. Eur. J. 2014, 20, 8654-8663.

(3) Reviews on heavier tetrylenes as ligands in homogeneous catalysts: (a) Raoufmoghaddam, S.; Zhou, Y.-P.; Wang, Y.; Driess, M. N-heterocyclic silylenes as powerful steering ligands in catalysis. J. Organomet. Chem. 2017, 829, 2-10. (b) Blom, B.; Gallego, D.; Driess, M. Nheterocyclic silylene complexes in catalysis: new frontiers in an emerging field. Inorg. Chem. Front. 2014, 1, 134-148.

(4) Articles on non-pincer heavier tetrylenes as ligands in homogeneous catalysis not cited in ref. 3: (a) Álvarez-Rodríguez, L.; Cabeza, J. A.; García-Álvarez, P.; Pérez-Carreño, E. Ruthenium Carbene Complexes Analogous to Grubbs-I Catalysts Featuring Germylenes as Ancillary Ligands. Organometallics 2018, 37, DOI: 10.1021/acs.organomet.7b00905. (b) Schmidt, M.; Blom, B.; Szilvási, T.; Schomacker, R.; Driess, M. Improving the Catalytic Activity in the RhodiumMediated Hydroformylation of Styrene by a Bis(N-heterocyclic silylene) Ligand. Eur. J. Inorg. Chem. 2017, 1284-1291. (c) Limura, T.; Akasaka, N.; Kosai, T.; Iwamoto, T. A Pt(0) complex with cyclic (alkyl)(amino)silylene and 1,3-divinyl-1,1,3,3-tetramethyldisiloxane ligands: synthesis, molecular structure, and catalytic hydrosilylation activity. Dalton Trans. 2017, 46, 8868-8874. (d) Limura, T.; Akasaka, N.; Kosai, T.; Iwamoto, T. A Dialkylsilylene-Pt(0) Complex with a DVTMS Ligand for the Catalytic Hydrosilylation of Functional Olefins. Organometallics 2016, 35, 4071-4076. (e) Álvarez-Rodríguez, L.; Cabeza, J. A.; Fernández-Colinas, J. M.; GarcíaÁlvarez, P. Amidinatogermylene Metal Complexes as Homogeneous Catalysts in Alcoholic Media. Organometallics 2016, 35, 2516-2523. (f) Zhou, Y.-P.; Raoufmoghaddam, S.; Szilvási, T.; Driess, M. A Bis(silylene)-Substituted ortho-Carborane as a Superior Ligand in the NickelCatalyzed Amination of Arenes. Angew. Chem. Int. Ed. Engl. 2016, 55, 12868-12872. (g) Xu, S.; Boschen, J. S.; Biswas, A.; Kobayashi, T.; Pruski, M.; Windus, T. L.; Sadow, A. D. Mild partial deoxygenation of esters catalyzed by an oxazolinylborate-coordinated rhodium silylene. Dalton Trans. 2015, 44, 15897-15904. (h) Smart, K. A.; Mothes-Martin, E.; Vendier, L.; Perutz, R. N.; Grellier, M.; Sabo-Etienne, S. A Ruthenium Dihydrogen Germylene Complex and the Catalytic Synthesis of Digermoxane. Organometallics 2015, 34, 4158-4163. (i) Kireenko, M. M.; Zaitsev, K. V.; Oprunenko, Y. F.; Churakov, A. V.; Tafeenko, V. A.; Karlov, S. S.; Zaitseva, G. S. Palladium complexes with stabilized germylene and stannylene ligands. Dalton Trans. 2013, 42, 
7901-7912. (j) Fasulo, M. E.; Lipke, M. C.; Tilley, T. D. Structural and mechanistic investigation of a cationic hydrogen-substituted ruthenium silylene catalyst for alkene hydrosilation. Chem. Sci. 2013, 4, 3882-3887. (k) Calimano, E.; Tilley, T. D. Synthesis and Structure of PNP-Supported Iridium Silyl and Silylene Complexes: Catalytic Hydrosilation of Alkenes. J. Am. Chem. Soc. 2009, 131, 11161-11173. (1) Calimano, E.; Tilley, T. D. Alkene Hydrosilation by a Cationic Hydrogen-Substituted Iridium Silylene Complex. J. Am. Chem. Soc. 2008, 130, 9226-9227. (m) Waterman, R.; Hayes, P. G.; Tilley, T. D. Synthetic Development and Chemical Reactivity of Transition-Metal Silylene Complexes. Acc. Chem. Res. 2007, 40, 712-719. (n) Glaser, P. B.; Tilley, T. D. Catalytic Hydrosilylation of Alkenes by a Ruthenium Silylene Complex. Evidence for a New Hydrosilylation Mechanism. J. Am. Chem. Soc. 2003, 125, 13640-13641. (o) Litz, K. E.; Bender IV, J. E.; Kampf, J. W.; Holl, M. M. B. Transition Metal Germylene Complexes as Hydrogenation Catalysts: The Synthesis of a Rare Bis(amino)germane. Angew. Chem. Int. Ed. 1997, 36, 496-498.

(5) Recent reviews on pincer complexes and their applications: (a) Peris, E.; Crabtree, R. H. Key factors in pincer ligand design. Chem. Soc. Rev. 2018, 47, 1959-1968. (b) Balakrishna, M. S. Unusual and rare pincer ligands: Synthesis, metallation, reactivity and catalytic studies. Polyhedron 2018, 143, 2-10. (c) Maser, L.; Vondung, L.; Langer, R. The ABC in pincer chemistry: From amine- to borylene- and carbon-based pincer-ligands. Polyhedron 2018, 143, 2842. (d) Fernández-Álvarez, F. J.; Lalrempuia R.; Oro, L. A. Monoanionic NSiN-type ligands in transition metal coordination chemistry and catalysis. Coord. Chem. Rev. 2017, 350, 49-60. (e) The Privileged Pincer-Metal Platform: Coordination Chemistry \& Applications, van Koten, G.; Gossage, R. A. (Eds.), Springer: Cham, 2016. (f) Asay M.; Morales-Morales, D. Non-symmetric pincer ligands: complexes and applications in catalysis. Dalton Trans. 2015, 44, 17432-17447. (g) Gunanathan, C.; Milstein, D. Bond Activation and Catalysis by Ruthenium Pincer Complexes. Chem. Rev. 2014, 114, 12024-12087. (h) Organometallic Pincer Chemistry, van Koten, G.; Milstein, D. (Eds.), Springer: Heidelberg, 2013. (i) Choi, J.; MacArthur, A. H. R.; Brookhart, M.; Goldman, A. S. Dehydrogenation and Related Reactions Catalyzed by Iridium Pincer Complexes. Chem. Rev. 2011, 111, 1761-1779. (j) Selander, N.; Szabó, K. J. Catalysis by Palladium Pincer Complexes. Chem. Rev. 2011, 111, 2048-2076. (k) The Chemistry of Pincer Compounds, Morales-Morales, D.; Jensen, C. (Eds.), Elsevier Science: Amsterdam, 2007. (1) Makoto, Y. The Organometallic Chemistry of Boron-Containing Pincer Ligands based on Diazaboroles and 
Carboranes. Bull. Chem. Soc. Jpn. 2016, 89, 269-281. (m) Turculet, L. in The Chemistry of Pincer Compounds, Szabó, K. J.; Wendt, O. F. (Eds), Viley-VCH: Weinheim, 2014, pp. 149-187. (n) van der Vlugt, J. I. Boryl-Based Pincer Systems: New Avenues in Boron Chemistry. Angew. Chem. Int. Ed. 2010, 49, 252-255. (o) Benito-Garagorri, D.; Kirchner, K. Modularly Designed Transition Metal PNP and PCP Pincer Complexes based on Aminophosphines: Synthesis and Catalytic Applications. Acc. Chem. Res. 2008, 41, 201-213. (p) Pugh, D.; Danopoulos, A. A. Metal complexes with 'pincer'-type ligands incorporating $N$-heterocyclic carbene functionalities. Coord. Chem. Rev. 2007, 251, 610-641.

(6) Recent reviews on pincer complexes in homogeneous catalysis: (a) Bauer, G.; Hu, X. Recent developments of iron pincer complexes for catalytic applications. Inorg. Chem. Front. 2016, 3, 741-765. (b) Yonus, H. A.; Su, W.; Ahmad, N.; Chen, S.; Verpoort, F. Ruthenium Pincer Complexes: Synthesis and Catalytic Applications. Adv. Synth. Catal. 2015, 357, 283-330. (c) Catalysis by Pincer Complexes: Applications in Organic Synthesis and Catalysis, Szabó, K. J.; Wendt, O. F. (Eds.), Viley-VCH: Weinheim, 2014. (d) Dend, Q.-H.; Melen, R. L.; Gade, L. H. Anionic Chiral Tridentate N-Donor Pincer Ligands in Asymmetric Catalysis. Acc. Chem. Res. 2014, 47, 3162-3173.

(7) (a) Cabeza, J. A.; García-Álvarez, P.; González-Álvarez, L. Facile cyclometallation of a mesitylsilylene: synthesis and preliminary catalytic activity of iridium(III) and iridium(V) iridasilacyclopentenes. Chem. Commun. 2017, 53, 10275-10278. (b) Werner, H. Electron-Rich Half-Sandwich Complexes-Metal Bases par excellence. Angew. Chem. Int. Ed. Engl. 1983, 22, 927-949. (b) Shriver, D. F. Transition metal basicity. Acc. Chem. Res. 1970, 3, 231-238. (c) Collman, J. P.; Roper, W. R. Oxidative-Addition Reactions of $\mathrm{d}^{8}$ Complexes. Adv. Organomet. Chem. 1969, 7, 53-94. (d) Vaska, L. Reversible activation of covalent molecules by transitionmetal complexes. The role of the covalent molecule. Acc. Chem. Res. 1968, 1, 335-344.

(8) Hahn, F. E.; Zabula, A. V.; Pape, T.; Hepp, A. Preparation and Molecular Structures of Stable Bis(germylenes) with Pincer Topology. Eur. J. Inorg. Chem. 2007, 2405-2408.

(9) (a) Hahn, F. E.; Wittenbecher, L.; Kühn, M.; Lügger, T.; Fröhlich, R. A zwitterionic carbene-stannylene adduct via cleavage of a dibenzotetraazafulvalene by a stannylene. $J$. Organomet. Chem. 2001, 617-618, 629-634. (b) Hahn, F. E.; Wittenbecher, L.; Le Van, D.; 
Zabula, A. V. Benzimidazolin-2-stannylenes with $N, N^{\prime}$-Alkyl (Me and Et) and Lewis Base Functional Groups. Inorg. Chem. 2007, 46, 7662-7667.

(10) (a) Brück, A.; Gallego, D.; Wang, W.; Irran, E.; Driess, M.; Hartwig, J. F. Pushing the oDonor Strength in Iridium Pincer Complexes: Bis-(silylene) and Bis(germylene) Ligands Are Stronger Donors than Bis(phosphorus(III)) Ligands. Angew. Chem. Int. Ed. 2012, 51, 1147811482. (b) Wang, W.; Inoue, S.; Irran, E.; Driess, M. Synthesis and Unexpected Coordination of a Silicon(II)-Based SiCSi Pincerlike Arene to Palladium. Angew. Chem. Int. Ed. 2012, 51, 36913694. (c) Gallego, D.; Brück, A.; Irran, E.; Meier, F.; Kaupp, F.; Driess, M. From Bis(silylene) and Bis(germylene) Pincer-Type Nickel(II) Complexes to Isolable Intermediates of the NickelCatalyzed Sonogashira Cross-Coupling Reaction. J. Am. Chem. Soc. 2013, 135, 15617-15626.

(11) (a) Ren, H.; Zhou, Y.-P.; Bai, Y.; Cui, C.; Driess, M. Cobalt-Catalyzed Regioselective Borylation of Arenes: N-Heterocyclic Silylene as an Electron Donor in the Metal-Mediated Activation of C-H Bonds. Chem. Eur. J. 2017, 23, 5663-5667. (b) Zhou, Y.-P.; Karni, M.; Yao, S.; Apeloig, Y.; Driess, M. A Bis(silylenyl)pyridine Zero-Valent Germanium Complex and Its Remarkable Reactivity. Angew. Chem. Int. Ed. 2016, 55, 15096-15099. (c) Metsänen, T. T.; Gallego, D.; Szilvási, T.; Driess, M.; Oestreich, M. Peripheral mechanism of a carbonyl hydrosilylation catalysed by an SiNSi iron pincer complex. Chem. Sci. 2015, 6, 7143-7149. (d) Gallego, D.; Inoue, S.; Blom, B.; Driess, M. Highly Electron-Rich Pincer-Type Iron Complexes Bearing Innocent Bis(metallylene)pyridine Ligands: Syntheses, Structures, and Catalytic Activity. Organometallics 2014, 33, 6885-6897.

(12) Whited, M. T.; Zhang, J.; Ma, S.; Nguyen, B. D.; Janzen, D. E. Silylene-assisted hydride transfer to $\mathrm{CO}_{2}$ and $\mathrm{CS}_{2}$ at a $\left[\mathrm{P}_{2} \mathrm{Si}\right] \mathrm{Ru}$ pincer-type complex. Dalton Trans. 2017, 46, 14757-14761.

(13) DeMott, J. C.; Gu, W. X.; McCulloch, B. J.; Herbert, D. E.; Goshert, M. D.; Walensky, J. R.; Zhou, J.; Ozerov, O. V. Silyl-Silylene Interplay in Cationic PSiP Pincer Complexes of Platinum. Organometallics 2015, 34, 3930-3933.

(14) Handwerker, H.; Paul, M.; Blumel, J.; Zybill, C. Photochemical 1,2 Shift of the Phosphane Ligands in the Silanediyl Complex $\left[\left(2-\mathrm{Ph}_{2} \mathrm{PCH}_{2} \mathrm{C}_{6} \mathrm{H}_{4}\right)_{2} \mathrm{Si}=\mathrm{Cr}(\mathrm{CO})_{5}\right]$. Angew. Chem. Int. Ed. 1993, 32, 1313-1315. 
(15) Álvarez-Rodríguez, L.; Brugos, J.; Cabeza, J. A.; García-Álvarez, P.; Pérez-Carreño, E.; Polo, D. Synthesis and initial transition metal chemistry of the first PGeP pincer-type germylene. Chem. Commun. 2017, 53, 893-896.

(16) Álvarez-Rodríguez, L.; Brugos, J.; Cabeza, J. A.; García-Álvarez, P.; Pérez-Carreño, E. From a Diphosphanegermylene to Nickel, Palladium, and Platinum Complexes Containing Germyl PGeP Pincer Ligands. Chem. Eur. J. 2017, 23, 15107-15115.

(17) Brugos, J.; Cabeza, J. A.; García-Álvarez, P.; Pérez-Carreño, E.; Polo, D. Synthesis and some coordination chemistry of the PSnP pincer-type stannylene $\mathrm{Sn}\left(\mathrm{NCH}_{2} \mathrm{P}^{\prime} \mathrm{Bu}_{2}\right)_{2} \mathrm{C}_{6} \mathrm{H}_{4}$, attempts to prepare the PSiP analogue, and effect of the $\mathrm{E}$ atom on the molecular structures of $\mathrm{E}\left(\mathrm{NCH}_{2} \mathrm{P}^{t} \mathrm{Bu}_{2}\right)_{2} \mathrm{C}_{6} \mathrm{H}_{4}(\mathrm{E}=\mathrm{C}, \mathrm{Si}, \mathrm{Ge}, \mathrm{Sn})$. Dalton Trans. 2018, 47, 4534-4544.

(18) Mantina, M.; Chamberlin, A. C.; Valero, R.; Cramer, C. J.; Truhlar, D. G. Consistent van der Waals Radii for the Whole Main Group. J. Phys. Chem. A 2009, 113, 5806-5812.

(19) For XRD-characterized iridium(I)-germyl complexes, see: (a) Kameo, H.; Ikeda, K.; Bourissou, D.; Sakaki, S.; Takemoto, S.; Nakazawa, H.; Matsuzaka, H. Transition-MetalMediated Germanium-Fluorine Activation: Inverse Electron Flow in $\sigma$-Bond Metathesis. Organometallics 2016, 35, 713-719. (b) Kameo, H.; Ishii, S.; Nakazawa, H. Facile synthesis of rhodium and iridium complexes bearing a $[\mathrm{PEP}]$-type ligand $(\mathrm{E}=\mathrm{Ge}$ or $\mathrm{Sn})$ via $\mathrm{E}-\mathrm{C}$ bond cleavage. Dalton Trans. 2012, 41, 11386-11392. (c) Kameo, H.; Ishii, S.; Nakazawa, H. Synthesis of iridium complexes bearing $\left\{o-\left(\mathrm{Ph}_{2} \mathrm{P}\right) \mathrm{C}_{6} \mathrm{H}_{4}\right\}_{3} \mathrm{E}$ type $(\mathrm{E}=\mathrm{Si}, \mathrm{Ge}$, and $\mathrm{Sn})$ ligand and evaluation of electron donating ability of group 14 elements E. Dalton Trans. 2012, 41, 8290-8296. (d) Adams, R. D.; Trufan, E. Iridium-Germanium and -Tin Carbonyl Complexes. Organometallics 2010, 29, 4346-4353. (e) Allen, J. M.; Brennessel, W. W.; Buss, C. E.; Ellis, J. E.; Minyaev, M. E.; Pink, M.; Warnock, G. F.; Winzenburg, M. L.; Young Jr., V. G. Synthesis, Isolation, and Characterization of Trisodium Tricarbonyliridate (3-), $\mathrm{Na}_{3}\left[\operatorname{Ir}(\mathrm{CO})_{3}\right]$. Initial Studies on Its Derivative Chemistry and Structural Characterizations of trans-[ $\left.\operatorname{Ir}(\mathrm{CO})_{3}\left(\mathrm{EPh}_{3}\right)_{2}\right]^{-}, \mathrm{E}=\mathrm{Ge}, \mathrm{Sn}$, and trans- $\left[\mathrm{Co}(\mathrm{CO})_{3}\left(\mathrm{SnPh}_{3}\right)_{2}\right]^{-}$. Inorg. Chem. 2001, 40, 5279-5284.

(20) Hawkins, S. M.; Hitchcock, P. B.; Lappert, M. F.; Rai, A. K. Iridium(III) hydrides derived from an iridium(I) substrate by oxidative addition and cyclometallation of germanium(II) bis(trimethylsilyl)amide; $\quad X$-ray structures of $\quad\left[\left\{\mathrm{CH}_{2} \mathrm{Me}_{2} \mathrm{SiN}(\mathrm{R})\left(\mathrm{NR}_{2}\right) \mathrm{Ge}\right\} \mathrm{HIr}(\mu\right.$ - 
$\left[\operatorname{lr}\left\{\mathrm{GeCl}\left(\mathrm{NR}_{2}\right) \mathrm{N}(\mathrm{R}) \mathrm{SiMe}_{2} \mathrm{CH}_{2}\right\}(\mathrm{CO})_{2} \mathrm{H}\left\{\mathrm{Ge}\left(\mathrm{NR}_{2}\right)_{2}\right\}\right]\left(\mathrm{R}=\mathrm{SiMe}_{3}\right)$. J. Chem. Soc., Chem. Commun. 1986, 1689-1690.

(21) Whited, M. T.; Deetz, A. M.; Boerma, J. W.; DeRosha, D. E.; Janzen, D. E. Formation of Chlorosilyl Pincer-Type Rhodium Complexes by Multiple $\mathrm{Si}-\mathrm{H}$ Activations of Bis(phosphine)/Dihydrosilyl Ligands. Organometallics 2014, 33, 5070-5073.

(22) (a) Job, R. C; Curtis, M. D. Photochemistry of some bis(metal carbonyl) germanes and (metal carbonyl)chlorogermanes. Formation of germanium-bridged metal-metal bonds. Inorg. Chem. 1973, 12, 2514-2519. (b) Lei, D.; Hampden-Smith, M. J.; Duesler, E. N.; Huffman, J. C. Synthesis and single-crystal $\mathrm{x}$-ray structural investigation of 1,1-bis(pentacarbonylmanganio)-3,4dimethylgermacyclopent-3-ene and bis[1-(tetracarbonylferrio)-3,4-dimethylgermacyclopent-3ene]: the first evidence for a puckered ground-state conformation in germacyclopent-3-enes. Inorg. Chem. 1990, 29, 795-798. (c) Herrmann, W. A.; Kneuper, H.-J.; Herdtweck, E. Mehrfachbindungen zwischen Hauptgruppenelementen und Übergangsmetallen, LVIII. Germylen= und Germanium-Komplexe des Mangans. Chem. Ber. 1989, 122, 433-436. (d) Ismail, M. L. B.; Liu, F.-Q.; Yim, W.-L.; Ganguly, R.; Li, Y.; So, C. W. Reactivity of a Base-Stabilized Germanium(I) Dimer toward Group 9 Metal(I) Chloride and Dimanganese Decacarbonyl. Inorg. Chem. 2017, 56, 5402-5410.

(23) Veith, M.; Stahl, L.; Huch, V. Reactions of Cyclic Bis(amino)germylenes and -stannylenes with $\left[\mathrm{CpFe}(\mathrm{CO})_{2}\right]_{2}$ and $\mathrm{CpFe}(\mathrm{CO})_{2} \mathrm{Me}\left(\mathrm{Cp}=\eta^{5}-\mathrm{C}_{5} \mathrm{H}_{5}\right)$. Syntheses and Single-Crystal X-ray Structures of Four New Insertion Compounds. Organometallics 1993, 12, 1914-1920.

(24) See, for example: (a) Esteruelas, M. A.; Herrero, J.; Oro, L. A. Exclusive formation of cis$\mathrm{PhCH}: \mathrm{CH}\left(\mathrm{SiEt}_{3}\right)$ by addition of triethylsilane to phenylacetylene catalyzed by the ruthenium complex $\left[\left(\mathrm{Me}_{2} \mathrm{CH}\right)_{3} \mathrm{P}\right]_{2} \mathrm{RuHCl}(\mathrm{CO})$. Organometallics 1993, 12, 2377-2379. (b) Esteruelas, M. A.; Gómez, A. V.; Lahoz, F. J.; López, A. M.; Oñate, E.; Oro, L. A. Five-Coordinate Complex $\left[\mathrm{RuHCl}(\mathrm{CO})\left(\mathrm{PPr}_{3}^{\mathrm{i}}\right)_{2}\right]$ as a Precursor for the Preparation of New Cyclopentadienylruthenium Compounds Containing Unsaturated $\eta^{1}$-Carbon Ligands. Organometallics 1996, 15, 3423-3425. 
(25) Herrmann, R.; Braun, T.; Mebs, S. $\left[\mathrm{Ge}(\mathrm{H})\left(2-\mathrm{C}_{6} \mathrm{H}_{4} \mathrm{PPh}_{2}\right)_{3}\right]$ as Ligand Precursor at Ruthenium: Formation and Reactivity of $\left[\mathrm{Ru}(\mathrm{Cl})\left\{\mathrm{Ge}\left(2-\mathrm{C}_{6} \mathrm{H}_{4} \mathrm{PPh}_{2}\right)_{3}\right\}\right]$. Eur. J. Inorg. Chem. 2014, $4826-2835$.

(26) Filippou, A. C.; Weidemann, N.; Philippopoulos, A. I.; Schnakenburg, G. Activation of Aryl Germanium(II) Chlorides by $\left[\mathrm{Mo}\left(\mathrm{PMe}_{3}\right)_{6}\right]$ and $\left[\mathrm{W}\left(\eta^{2}-\mathrm{CH}_{2} \mathrm{PMe}_{2}\right) \mathrm{H}\left(\mathrm{PMe}_{3}\right)_{4}\right]$ : A New Route to Metal-Germanium Triple Bonds. Angew. Chem. Int. Ed. 2006, 45, 5987-5991.

(27) Hupp, F.; Ma, M.; Kroll, F.; Jiménez-Halla, J. O. C.; Dewhurst, R. D.; Radacki, K.; Stasch, A.; Jones, C.; Braunschweig, H. Platinum Complexes Containing Pyramidalized Germanium and Tin Dihalide Ligands Bound through $\sigma, \sigma \mathrm{M}=\mathrm{E}$ Multiple Bonds. Chem. Eur. J. 2014, 20, 16888-16898.

(28) (a) Cabeza, J. A.; Fernández-Colinas, J. M.; García-Álvarez, P.; Polo, D. Diaminogermylene and Diaminostannylene Derivatives of Gold(I): Novel AuM and $\mathrm{AuM}_{2}(\mathrm{M}=$ Ge, Sn) Complexes. Inorg. Chem. 2012, 51, 3896-3903. (b) York, J. T.; Young, V. G.; Tolman, W. B. Heterobimetallic Activation of Dioxygen: Characterization and Reactivity of Novel $\mathrm{Cu}(\mathrm{I})-\mathrm{Ge}(\mathrm{II})$ Complexes. Inorg. Chem. 2006, 45, 4191-4198. (c) Cygan, Z. T.; Bender IV, J. E.; Litz, K. E.; Kampf, J. W.; Holl, M. M. B. Synthesis and Reactivity of a Novel Palladium Germylene System. Organometallics 2002, 21, 5373-5381. (d) Litz, K. E.; Bender IV, J. E.; Kampf, J. W.; Holl, M. M. B. Transition Metal Germylene Complexes as Hydrogenation Catalysts: The Synthesis of a Rare Bis(amino)germane. Angew. Chem. Int Ed. 1997, 36, 496-498. (e) Litz, K .E.; Henderson, K.; Gourley, R. W.; Holl, M. M. B. Reversible Insertion Reactions of a Platinum Germylene Complex. Organometallics 1995, 14, 5008-5010.

(29) (a) Herrmann, W. A.; Denk, M.; Behm, J.; Scherer, W.; Klingan, F.-R.; Bock, H.; Solouki, B.; Wagner, M. Stable Cyclic Germanediyls ("Cyclogermylenes"): Synthesis, Structure, Metal Complexes, and Thermolyses. Angew. Chem. Int. Ed. 1992, 31, 1485-1488. (b) Ullah, F.; Kühl, O.; Bajor, G.; Veszpremi, T.; Jones, P. G.; Heinicke, J. Transition Metal Complexes of NHeterocyclic Germylenes. Eur. J. Inorg. Chem. 2009, 221-229. (c) Bazinet, P.; Yap, G. P. A.; Richeson, D. S. Synthesis and Properties of a Germanium(II) Metalloheterocycle Derived from 1,8-Di(isopropylamino)naphthalene. A Novel Ligand Leading to Formation of $\mathrm{Ni}\left\{\mathrm{Ge}\left[(\mathrm{iPrN})_{2} \mathrm{C}_{10} \mathrm{H}_{6}\right]\right\}_{4}$. J. Am. Chem. Soc. 2001, 123, 11162-11167. (d) Hahn, F. E.; Zabula, A. 
V.; Pape, T.; Hepp, A. Benzannulated Bisgermylenes - Aggregation Behavior and Coordination Chemistry. Z. Anorg. Allg. Chem. 2008, 634, 2397-2401. (e) Kühl, O. Lönnecke, P.; Heinicke, J.

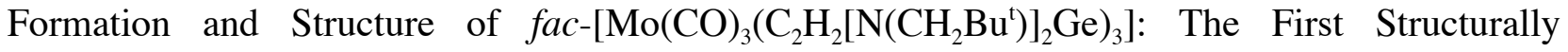
Characterized Group 6 Transition Metal Complex of an Unsaturated Diaminogermylene. Inorg. Chem. 2003, 42, 2836-2838. (f) Veith, M.; Muller, A.; Stahl, L.; Notzel, M.; Jarczyk, M.; Huch, V. Formation of Metal Clusters or Nitrogen-Bridged Adducts by Reaction of a Bis(amino)stannylene with Halides of Two-Valent Transition Metals. Inorg. Chem. 1996, 35, 3848-3855. (g) Walz, F.; Moos, E.; Garnier, D.; Koppe, R.; Anson, C. E.; Breher, F. A RedoxSwitchable Germylene and its Ligating Properties in Selected Transition Metal Complexes. Chem. Eur. J. 2017, 23, 1173-1186. (h) Veith, M.; Stahl, L. Novel Insertions of Carbene Homologues into Metal- $\eta^{5}-\mathrm{Cp}$ Bonds: Sandwich Complexes with $\mathrm{Ge}_{2} \mathrm{Ni}$ and $\mathrm{Sn}_{2} \mathrm{Ni}$ Cores. Angew. Chem. Int . Ed. 1993, 32, 106-107. (i) Zabula, A. V.; Hahn, F. E.; Pape, T.; Hepp, A. Preparation and Coordination Chemistry of Bidentate Benzimidazoline-2-germylenes. Organometallics 2007, 26, 1972-1980.

(30) Herde, J. L.; Lambert, J. C.; Senoff, C. V.; Cushing, M. A. Cyclooctene and 1,5Cyclooctadiene Complexes of Iridium(I). Inorg. Synth. 1974, 15, 18-20.

(31) Esteruelas, M. A.; Werner, H. Five- and six-coordinate hydrido(carbonyl)-ruthenium(II) and -osmium(II) complexes containing triisopropylphosphine as ligand. J. Organomet. Chem. 1986, 303, 221-231.

(32) CrysAlisPro RED, version 1.171.38.46; Oxford Diffraction Ltd.: Oxford, U.K., 2015.

(33) SIR-97: Altomare, A.; Burla, M. C.; Camalli, M.; Cascarano, G.; Giacovazzo, C.; Guagliardi, A.; Moliterni, A. G. C.; Polidori, G.; Spagna, R. SIR97: a new tool for crystal structure determination and refinement. J. Appl. Crystallogr. 1999, 32, 115-119.

(34) SHELXL-2014: Sheldrick, G. M. A short history of SHELX. Acta Crystallogr., Sect. A: Found. Crystallogr. 2008, 64, 112-122.

(35) XHYDEX: Orpen, A. G. Indirect location of hydride ligands in metal cluster complexes. $J$. Chem. Soc., Dalton Trans. 1980, 2509-2516. 
(36) WINGX, version 2013.3: Farrugia, L. J. WinGX and ORTEP for Windows: an update. J. Appl. Crystallogr. 2012, 45, 849-854.

(37) MERCURY, CSD 3.9 (build RC1); Cambridge Crystallographic Data Centre: Cambridge, U.K., 2016.

(38) Chai, J.-D.; Head-Gordon, M. Long-range corrected hybrid density functionals with damped atom-atom dispersion corrections. Phys. Chem. Chem. Phys. 2008, 10, 6615-6620.

(39) (a) Ehrlich, S.; Moellmann, J.; Grimme, S. Dispersion-Corrected Density Functional Theory for Aromatic Interactions in Complex Systems. Acc. Chem. Res. 2013, 46, 916-926. (b) Grimme, S. Density functional theory with London dispersion corrections. Comp. Mol. Sci. 2011, 1, 211-218. (c) Schwabe, T.; Grimme, S. Theoretical Thermodynamics for Large Molecules: Walking the Thin Line between Accuracy and Computational Cost. Acc. Chem. Res. 2008, 41, $569-579$.

(40) Minenkov, Y.; Singstad, Å; Occhipinti, G.; Jensen, V. R. The accuracy of DFT-optimized geometries of functional transition metal compounds: a validation study of catalysts for olefin metathesis and other reactions in the homogeneous phase. Dalton Trans. 2012, 41, 5526-5541.

(41) Figgen, D.; Peterson, K. A.; Dolg, M.; Stoll, H. Energy-consistent pseudopotentials and correlation consistent basis sets for the $5 d$ elements Hf-Pt. J. Chem. Phys. 2009, 130, 164108164120.

(42) Peterson, K. A.; Figgen, D.; Dolg, M.; Stoll, H. Energy-consistent relativistic pseudopotentials and correlation consistent basis sets for the $4 d$ elements Y-Pd. J. Chem. Phys. 2007, 126, 124101-124112.

(43) Dunning, T. H. Gaussian basis sets for use in correlated molecular calculations. I. The atoms boron through neon and hydrogen. J. Chem. Phys. 1989, 90, 1007-1023.

(44) Glendening, E. D.; Reed, A. E.; Carpenter, J. E.; Weinhold, F. NBO 3.1, Theoretical Chemistry Institute, University of Wisconsin: Madison, 2002.

(45) Frisch, M. J.; Trucks, G. W.; Schlegel, H. B.; Scuseria, G. E.; Robb, M. A.; Cheeseman, J. R.; Scalmani, G.; Barone, V.; Mennucci, B.; Petersson, G. A.; Nakatsuji, H.; Caricato, M.; Li, X.; 
Hratchian, H. P.; Izmaylov, A. F.; Bloino, J.; Zheng, G.; Sonnenberg, J. L.; Hada, M.; Ehara, M.; Toyota, K.; Fukuda, R.; Hasegawa, J.; Ishida, M.; Nakajima, T.; Honda, Y.; Kitao, O.; Nakai, H.; Vreven, T.; Montgomery, J. A., Jr.; Peralta, J. E.; Ogliaro, F.; Bearpark, M.; Heyd, J. J.; Brothers, E.; Kudin, K. N.; Staroverov, V. N.; Kobayashi, R.; Normand, J.; Raghavachari, K.; Rendell, A.; Burant, J. C.; Iyengar, S. S.; Tomasi, J.; Cossi, M.; Rega, N.; Millam, J. M.; Klene, M.; Knox, J. E.; Cross, J. B.; Bakken, V.; Adamo, C.; Jaramillo, J.; Gomperts, R.; Stratmann, R. E.; Yazyev, O.; Austin, A. J.; Cammi, R.; Pomelli, C.; Ochterski, J. W.; Martin, R. L.; Morokuma, K.; Zakrzewski, V. G.; Voth, G. A.; Salvador, P.; Dannenberg, J. J.; Dapprich, S.; Daniels, A. D.; Farkas, O.; Foresman, J. B.; Ortiz, J. V.; Cioslowski, J.; Fox, D. J. Gaussian 09, revision A.01; Gaussian, Inc.: Wallingford, CT, 2009. 